\title{
NAJSTARSZE DOKUMENTY PERGAMINOWE (XIV-XVII WIEKU) W ZBIORACH RECKOPISÓW BIBLIOTEKI UNIWERSYTECKIEJ KUL
}

W zbiorach rękopiśmiennych Biblioteki Uniwersyteckiej KUL przechowywane są dokumenty i listy zwane umownie dyplomami, które traktowane są jako samodzielne jednostki biblioteczne. Stanowią one odrębną grupę skatalogowaną w Inwentarzu dyplomó $w^{l}$, w odróżnieniu od zbiorów rękopiśmiennych inwentaryzowanych w Inwentarzu ogólnym rękopisów BU KUL oraz w katalogu akcesyjnym tzw. tymczasowym. Wydzielenie dokumentów z ogólnego zbioru rękopisów zapoczątkował profesor Andrzej Wojtkowski, który w latach 1945-1949 opracował 67 jednostek opisując je w inwentarzu na sygnaturach dypl. 1-682. Pracę prof. Wojtkowskiego w latach 1967-1978 kontynuowała pani kustosz Helena Mańkowska, wpisując do Inwentarza dyplomów 17 jednostek rękopiśmiennych na sygnaturach dypl. 69-863. W roku $1968 \mathrm{w} 17$ tomie czasopisma „Archiwa, Biblioteki i Muzea Kościelne" Helena Mańkowska opublikowała Katalog dokumentów Biblioteki KUL $L^{4}$, obejmujący 71 dokumentów. Większość zawartych tam opisów (sygn. dypl. 1-68) dotyczy dokumentów, które pierwotnie zostały sporządzone KUL.

* Angelika Modlińska-Piekarz - dr neolatynistyki, kustosz w Bibliotece Uniwersyteckiej

${ }^{1}$ Inwentarz dyplomów Biblioteki Uniwersyteckiej KUL, Lublin 1949-2007 (rękopis), oprac.: 1) A. Wojtkowski, k. 1 r.-23 r. 2) H. Mańkowska, k. 23 r.-29 r. 3) A. Modlińska-Piekarz, 29 r.-53 v. oraz wersja komputerowa + indeks.

${ }^{2}$ Sygn. dypl. 35 do 2007 roku pozostawała wolna, gdyż omyłkowo znajdowała się na niej pierwotnie umieszczona przez prof. Andrzeja Wojtkowskiego fototypia dokumentu z publikacji paleograficznych, którą później z inwentarza wykreślono. Aktualnie sygnatura ta została uzupełniona oryginalnym dokumentem opracowanym w 2007 roku.

${ }^{3}$ Sygn. dypl. 82 została przez H. Mańkowską pominięta w Inwentarzu dyplomów z powodu błędu w numeracji. Aktualnie sygnatura ta została uzupełniona oryginalnym dokumentem opracowanym w 2007 roku.

${ }^{4}$ Katalog dokumentów Biblioteki Uniwersyteckiej KUL, oprac. H. Mańkowska, „Archiwa, Biblioteki i Muzea Kościelne", 17 (1968) [strony]- cytowany dalej jako Katalog dokumentów Biblioteki Uniwersyteckiej KUL. 
przez prof. Wojtkowskiego ${ }^{5}$. Zostały one przez panią Mańkowską poprawione i uzupełnione zgodnie z ówczesnymi wymogami wydawniczymi. Od roku 1978 prac nad dyplomami nie prowadzono aż do 2001, kiedy to autorka niniejszego artykułu rozpoczęła opracowanie dalszych 142 dokumentów i obecnie przygotowuje do druku Nowy katalog dokumentów i listów Biblioteki Uniwersyteckiej $K U L^{6}$, obejmujący wszystkie 226 sygnatur. Został on opracowany według współcześnie obowiązujących zasad katalogowania tego typu źródeł i uzupełniony odpowiednią bibliografią ${ }^{7}$. Prezentowany wybór szesnastu dyplomów ${ }^{8}$ został w niniejszym referacie ograniczony (ze względów wydawniczych) tylko do najbardziej interesujących pod względem historycznym dokumentów pergaminowych, dotyczących Lublina i Lubelszczyzny od XIV do XVII wieku. Poza Lublinem dokumenty odnoszą się do Wąwolnicy, Lewartowa (dziś Lubartowa), Wysokiego i Czemiernik, wszystkie przedstawiono w porządku chronologicznym. Niewątpliwie dokumenty dotyczące Lublina i Lubelszczyzny należą do najcenniejszych dokumentów Biblioteki KUL. Dyplomy obejmują lata 1371-1665 i stanowią bogaty materiał źródłowy, istotny do poznania stosunków politycznych, gospodarczych i społecznych ziem dawnego województwa lubelskiego. Wśród nich są przywileje lokacyjne i handlowe dla miast (Lublina, Lewartowa, Czemiernik), zabezpieczenie dóbr, dokumenty poświadczające rozstrzygnięcia sporów, potwierdzenia transakcji, a także przywileje i statuty jednego lubelskich z cechów.

Napisane są w języku polskim i łacińskim: najwięcej jest dokumentów napisanych w języku łacińskim $(1,2,3,4,5,6,7,8,9,11,15,16)$, dwa napisano w języku polskim (nr 10, 12), a dwa są dwujęzyczne: łacińsko-polskie (nr 13, 14). Wśród nich dziesięć dokumentów zostało wystawionych przez polskich władców: Elżbietę Łokietkównę (1), Ludwika Węgierskiego (2), Kazimierza Jagiellończyka $(3,4)$, Aleksandra Jagiellończyka (8), Zygmunta Augusta (11, 12), Zygmunta III Wazę 13, 14) i Jana Kazimierza (16), dwa przez hierarchów kościelnych: Mikołaja opata zakonu cystersów w Koprzywnicy (5) oraz Tomasza Oborskiego sufragana krakowskiego (15), jeden przez rajców sześciu miast: Krakowa, Sącza, Kazimierza, Wieliczki, Bochni i (6), pozostałe trzy dokumenty zostały wystawione przez Piotra Firleja sędziego ziemskiego lubelskiego i Piotra Pszonkę podsędka ziem-

${ }^{5} \mathrm{Z}$ powodu wspomnianej wyżej pomyłki (zob. przypis nr 2) w Katalogu Mańkowskiej wystąpiła luka w numeracji: dokumenty mają w katalogu numery 1-71, a obejmują sygnatury 1-72 (bez sygn. 35).

${ }^{6}$ Publikacja przewidziana w Wydawnictwie KUL na drugą połowę 2011 r., liczy ok. 133 stron tekstu + ilustracje.

${ }^{7}$ Nowy katalog został ponadto wzbogacony wykazem dokumentów transumowanych, inserowanych, widymowanych i poświadczających wpisy do ksiąg sądowych, konkordancją sygnatur Inwentarza dyplomów Biblioteki Uniwersyteckiej KUL, Katalogu dokumentów Biblioteki Uniwersyteckiej KUL opracowanego przez Helenę Mańkowską i numerów dokumentów według nowego katalogu. Istotnym uzupełnieniem nowego opracowania są również dwa indeksy nazw własnych. Pierwszy zawiera nazwy osobowe oraz instytucji, drugi natomiast nazwy geograficzne miast, wsi, osad, rzek.

${ }^{8} \mathrm{~W}$ całym zbiorze znajdują się 33 dokumenty pergaminowe i 193 dokumenty papierowe, natomiast Lublina i Lubelszczyzny dotyczy ok. 150 jednostek od XIV do XX w. (pergaminowych i papierowych). 
skiego lubelskiego (7), Andrzeja Tęczyńskiego wojewodę krakowskiego i Jana Tęczyńskiego wojewodę bełzkiego (9) oraz Piotra Firleja wojewodę lubelskiego (10).

Z pośród przedstawionych tutaj dokumentów siedem pochodzi z Archiwum Akt Dawnych w Lublinie ${ }^{9}$, notują je bowiem kopiariusze ${ }^{10}$ i sumariusze ${ }^{11}$ dokumentów przechowywanych w skarbcu lubelskiego magistratu, z którego w niewyjaśnionych okolicznościach zniknęły pod koniec XIX wieku. W 1917 roku nabył je Jan Stecki włączając do swoich zbiorów w rodzinnym Łańcuchowie ${ }^{12}$. W jaki sposób dokumenty znalazły się w posiadaniu Jana Steckiego, nie wiadomo. Jan Riabinin w roku 1936 odnotował brak w skarbcu Magistratu 96 dokumentów, z czego 34 już wtedy figurowały w Katalogu rękopisów Biblioteki Publicznej im. H. Łopacińskiego, opracowanym przez Aleksandra Jaworowskiego ${ }^{13}$, a 61 uznano za

9 Nazwą tą posługuję się przy omawianiu dokumentów, których obecność po raz ostatni była odnotowana w latach 1827-1887, gdyż wtedy archiwum miejskie tak się oficjalnie nazywało. Natomiast w okresie 1888-1918 archiwum formalnie nie istniało, zaś nazwa Archiwum Państwowe w Lublinie zaczęła obowiązywać od 1 XII 1918 r. i używana jest do dnia dzisiejszego. Zob. Archiwum Państwowe w Lublinie i jego oddzialy w Chetmie, Kraśniku i Radzyniu Podlaskim. Przewodnik po zasobie archiwalnym, red. F. Cieślak i M. Trojanowska, t. 1, Lublin 1997, s.19-27.

${ }^{10}$ Specyfikacya Przywilejów i Praw Nayiasnieyszych Regnantow y Regnantek Polskich Miastu J.K.Mci Lublinowi względem Wolności od płacenia Cła y Myt Wszelkich, [księga zawiera kopie przywilejów z lat 1371-1676, spisano ją w 1751 r.]., APL KmL, sygn. 247 - cytowana dalej jako kopiariusz 1751 r.; Liber privilegiorum tum decretorum tam assesorialium quam commissorialium aliorumque iurium civitati Lublinensi pro iudicis advocatiali et scabinali serviens, ex originalibus sumptu advocati et scabinorum Lublinensium perscriptus, [zawiera kopie dokumentów z lat 13171762, spisana w 1763 r., APL KmL, sygn. 145 - cytowany dalej jako kopiariusz z 1763 r.

${ }^{11}$ Summarium privilegiorum, donationum, libertatumque civitati Lublinensi ab eius locatione usque ad moderna tempora concessorum nec non decretorum regalium commissorialiumque ac ordinationum rescriptorumque ac sancitorum e Consilio Permanenti favore civitatis Lublinensis emanatorum vigore sententiae - Commissionis Boni Ordinis in civitate Lublinensi agitatae per civitatem Lublinensem conscriptum ac ad eandem Commissionem porrectum, [zawiera regesty dokumentów z lat 1317-1780, spisany w 1781 r.], APL KmL, sygn. 248 - cytowany jako sumariusz z 1781 r.; Summariusz wszystkich przywilejów, praw, nadań przez najj. królów polskich m. Lublinowi służących, od czasu jego założenia aż do ostatnich czasów, z wyszczególnieniem dokładnej treści, co każdy przywilej w sobie obejmuje i z jakiej przyczyny został udzielony i do jakiego użytku, [spisany w 1841 r.], APL AmL, sygn. 151 - cytowany dalej jako sumariusz z 1841r; Sumariusz nieznanego autora, bez tytułu, zawierający - poza regestami dokumentów - także informacje o dziejach Lublina, opracowany w 1819 r., WBP im. H. Łopacińskiego rkps nr 146 - cytowany dalej jako sumariusz z 1819 r.; Summarjusz przywilejów i dekretów najj. królów polskich, niemniej uchwał z strony Magistratu lubelskiego wydanych, m. Lublinowi i cechom tegoż miasta służących, które się na teraz znajdują; w myśl reskryptu prześw. Kommissji w-dztwa Lubelskiego pod dn. 9/21 lipca 1836 r. zapadłego, sporządzony przez - Antoniego Beczalskiego, WBP im. H. Łopacińskiego rkps nr 514 cytowany dalej jako sumariusz z $1836 \mathrm{r}$.

${ }^{12}$ Wskazywać na to mogą streszczenia na odwrocie tych dokumentów sporządzone przez Steckiego z datą 5 i 6 IX $1917 \mathrm{r}$.

${ }^{13}$ Katalog rękopisów Biblioteki Publicznej im. H. Łopacińskiego, oprac. A. Jaworowski, Lublin 1913. 
zaginione ${ }^{14}$. Maria Trojanowska w Katalogu dokumentów miasta Lublina ubytek dokumentów z Archiwum Państwowego tłumaczy tym, że wiele dokumentów oryginalnych zostało wyniesionych i przywłaszczonych przez pracowników Magistratu, którzy je sprzedawali lub dawali w podarunku różnym osobom ${ }^{15}$. $\mathrm{Z}$ tego względu Marian Butkiewicz przypuszcza, że Stecki mógł je uzyskać drogą zakupu lub otrzymać w prezencie nie wiedząc, skąd pochodzą ${ }^{16}$. Niewątpliwie traktował je jako swoją prawnie nabytą własność, pieczętując własnymi inicjałami i sygnaturami. Przed wybuchem wojny raczej nie udostępniał swojej kolekcji do badań historycznych, gdyż żadne prace z tego okresu dokumentów tych nie cytują. Ujawnione zostały dopiero po wojnie, gdy Stecki sprzedał je Bibliotece KUL wraz z 22 innymi (pominiętymi tutaj) dokumentami o różnorodnej proweniencji. Miało to miejsce 2 czerwca $1950 \mathrm{r}$. W prezentowanym zbiorze są ponadto dwa inne dokumenty zakupione od Jana Steckiego, które nie pochodzą z Archiwum Akt Dawnych w Lublinie. Przedstawiono też dwa dokumenty należące niegdyś do cechu piekarskiego w Lublinie, które zostały przyjęte $\mathrm{z}$ rąk anonimowych darczyńców w 1949 i 1950 r., jeden dokument, zakupiony w 1973 od Zygmunta Nowakowskiego z Puław, oraz cztery inne pochodzące ze starych, przedwojennych zasobów Biblioteki. Niewątpliwie jednak wszystkie te dokumenty winny zwrócić uwagę badaczy przeszłości Lublina i regionu, gdyż obecnie uważa się je powszechnie za zaginione, niektóre zaś w ogóle nie były znane i nie uwzględniano informacji w nich zawartych w żadnych publikacjach naukowych. Celem niniejszego referatu jest zatem w pierwszej kolejności przywrócenie tych cennych źródeł nauce, jak również prześledzenie losów każdego z nich oraz ukazanie ich obecności w literaturze naukowej. Dlatego szczególną uwagę skierowano na przedstawienie dokładnego opisu fizycznego dokumentów, dokonanego z autopsji dla zweryfikowania niektórych błędów, niejasności i wątpliwości funkcjonujących w pracach historyków Lubelszczyzny, a fizyczne opisy opatrzono komentarzem źródłowym i bibliograficznym oraz uwagami proweniencyjnymi.

Wybrane dokumenty przedstawiają się zatem w sposób następujący:

\section{Dokument 1}

1371, 4 lipca, Kraków

In die S. Procopii confessoris, Cracoviae.

Elżbieta Łokietkówna królowa węgierska i polska zatwierdza i transumuje następujący przywilej króla Władysława Łokietka:

${ }^{14}$ J. Riabinin, Materiaty do historii Miasta Lublina 1317-1792, Lublin 1938, s. XXVI- XVII.

${ }^{15}$ Katalog dokumentów Archiwum Państwowego w Lublinie, część 1: Katalog dokumentów miasta Lublina, oprac. M. Trojanowska, Lublin 1996, s. 7-8. Pozycja cytowana dalej jako Katalog dokumentów miasta Lublina.

${ }^{16}$ M. Butkiewicz, Dyplomy w zbiorach Biblioteki Uniwersyteckiej KUL, „Roczniki Humanistyczne", 48 (2000) z. 2 (specjalny), s. 80. 
1320, 13 maja - 1332, 2 maja, in Iatka Pacholonis.

Władysław Łokietek król polski zwalnia mieszczan lubelskich od wszelkich myt i opłat na drogach i w miastach królestwa polskiego.

Oryg., perg., j. łac., $33 \times 24 \times 7,2 \mathrm{~cm}$.

Pieczęć Elżbiety Łokietkówny, w czerwonym wosku (średnica $35 \mathrm{~mm}$ ), w skórzanej torebce, kiedyś oderwana, obecnie przytwierdzona do dokumentu białym sznurkiem. Zob. T. Żebrawski, O pieczęciach dawnej Polski i Litwy, Kraków 1865, tabl. 15 nr 39.

Na odwrocie: No 5to... Privilegiorum Approbatio in... a theoloneo Civitatis Lublini Libertas. Anno Domini 1371 a Serenissima Elisabeth Regina Amen. Nro 3tio 1371. 1371 Absolutio a Theoloneo Elisabeth Regina Poloniae No 19. Część napisów zatarta i nieczytelna. Krótkie streszczenie dokumentu w języku polskim sporządzone przez Jana Steckiego w $1917 \mathrm{r}$.

U dołu dokumentu pieczątka tuszowa, napis napieczętny brzmi: KSIĘGOZBIÓR ŁAŃCUCHOWSKI nr 665.

Stan zachowania dokumentu: dobry. Dokument był bardzo zniszczony w dwóch miejscach, w jednym z tekstem, wycięty i podklejony papierem. Poddany konserwacji w 2002 r., posiada specjalną oprawę z osobnym miejscem na pieczęć.

Ze zbioru łańcuchowskiego Jana Steckiego. Akcesja: 69/1950/k.

Bibl. KUL, sygn. dypl. 38.

Rozważania rozpoczynamy od najstarszego dokumentu w zbiorach BU KUL - oryginału przywileju dla Lublina wydanego przez Elżbietę Łokietkównę 4 lipca 1371 r. Pierwsze wzmianki o tym dokumencie znajdują się w przywileju Władysława Jagiełły z 26 marca $1405 \mathrm{r}^{17}$. Jagiełło potwierdza w nim zniszczone w czasie pożaru (wedle zapewnień mieszczan) przywileje dla mieszkańców Lublina wystawione przez swoich poprzedników, Władysława Łokietka, Kazimierza Wielkiego i Ludwika oraz królowe: Elżbietę i Jadwigę. Zagadką dla współczesnych historyków jest fakt, że dwa spośród wymienionych dokumentów, tj. dokument Elżbiety i Ludwika Węgierskiego zachowały się w Archiwum Akt Dawnych w Lublinie co najmniej do 1887 roku, ich odpisy ${ }^{18}$ i regesty ${ }^{19}$ znajdują się w lubelskich kopiariuszach i sumariuszach z XVIII I XIX w., a Franciszek Piekosiński drukował je z oryginału w Kodeksie Dyplomatycznym Małopolski jeszcze w 1887 $\mathrm{roku}^{20}$. Trudno dziś stwierdzić, dlaczego mieszczanie zapewnili króla, że dawne przywileje zostały spalone, skoro dokumenty Łokietkówny i Ludwika zachowały się do naszych czasów. Prawdopodobnie niektóre przywileje uległy spaleniu, ale co najmniej dwa musiały być poza miejscem pożaru i ocalały, a już w późniejszym czasie wróciły w posiadanie mieszczan. Do zupełnie innych wniosków do-

${ }^{17}$ Druk: Kodeks Dyplomatyczny Małopolski (dalej w skrócie: KDM), wyd. F. Piekosiński, t. 4, Kraków 1905, nr 1088, s. 96-97.

${ }^{18}$ Odpisy: kopiariusz 1751 r., k. 1 r.-1v.; kopiariusz z 1763 r, s. 17v.-18r.; (dokument Elżbiety Łokietkówny); Kopiariusz z 1763 r., k. 18 r. (dokument Ludwika Węgierskiego).

${ }^{19}$ Regesty: sumariusz z 1781 r. s. 2; sum. z 1819 r. nr 3; sum. z 1836 r. nr 3; sum. z $1841 \mathrm{nr} 3$ (dokument Elżbiety Łokietkówny); Sumariusz z 1781 r., s. 2-3; sum. z 1819 r., nr 4; sum. z 1836 r., nr 4; sum. z 1841 r., nr 4 (dokument Ludwika Węgierskiego).

${ }^{20}$ KDM, wyd. F. Piekosiński, Kraków 1887, t. 3, nr 843, s. 253-254 (dokument Elżbiety Łokietkówny); t. 3, nr 880, s. 295-296 (dokument Ludwika Węgierskiego). 
szedł Kazimierz Myśliński ${ }^{21}$. Mając do dyspozycji jedynie kopię transumptu Elżbiety ${ }^{22}$ i nie znając oryginału tych dwóch dokumentów, na podstawie dokumentu Jagiełły wywnioskował, iż dokumenty Łokietkówny i Ludwika, które opublikował Piekosiński, nie mogły być oryginałami, lecz późniejszymi falsyfikatami!:

Dotychczas nikt nie kwestionował autentyczności wszystkich tych dokumentów wystawionych jakoby przed 1405 rokiem. Żadnych wątpliwości nie podnosił ich wydawca, Franciszek Piekosiński. Niemniej takie wątpliwości się nasuwają. Przede wszystkim podnieść należy jedno. W uwagach do wydań przywilejów z 1371 i 1376 r. w kodeksie Małopolskim wydawca zanotował, że miał w ręku oryginały przechowywane wówczas w Archiwum Miasta Lublina. Pierwszy miał być opatrzony pieczęcią z czerwonego wosku, zawieszoną na pergaminowym pasku, drugi był bez pieczęci. [...] Wydawca regestów dokumentów lubelskich J. Riabinin, nie widział już ani jednego ani drugiego oryginału, gdyż w międzyczasie zginęły $\mathrm{z}$ archiwum miejskiego. Nie znamy metody pracy Piekosińskiego. Nie wiemy więc, czy oglądał owe oryginały sam, czy też zdał się na informację i odpis któregoś ze swoich lubelskich współpracowników. Nie może jednak ulegać najmniejszej wątpliwości, że dokumenty, jakie oglądał w magistrackim archiwum lubelskim przygotowując Kodeks Małopolski, nie były oryginałami, lecz późniejszymi kopiami. Jakże bowiem mogły oryginały przetrwać do ostatnich czasów, skoro sam Jagiełło w przywileju z 1405 roku powiada, że wszystkie poprzednio wystawione przywileje się spaliły i że rajcy, występując o ich zatwierdzenie niczego nie mogli przedstawić oprócz własnego ustnego świadectwa. Nie mieli nawet kopii. A nie mamy powodu nie wierzyć dokumentowi Jagiełły, skoro jego oryginał zachował się do dziś dnia. W 1405 roku nie istniały więc ani oryginały ani kopie owych czternastowiecznych przywilejów zwalniających Lublin od ceł w całym państwie. Wynika z tego, że to, co przechowało się w archiwum miejskim Lublina w końcu XIX wieku było po prostu późniejszym falsyfikatem. Dokument z 1405 roku jest najpoważniejszym argumentem za nieautentycznością trzech starych przywilejów lubelskich ${ }^{23}$.

Z powyższego cytatu wynika, że Myśliński uważał, iż albo Piekosiński osobiście nie widział pergaminowych oryginałów, i mając wiadomość z drugiej ręki, podał nieścisłe informacje na ich temat, albo te dokumenty widział, lecz nie dostrzegł, że są późniejszymi falsyfikatami. Jednak nawet w jego własnym wywodzie jest furtka, która zdaje się otwierać na rozwiązanie tej zagadki, a której nie dostrzegł sam autor, traktując owe dokumenty jako zaginione:

Najpoważniejsze wątpliwości co do autentyczności najstarszych lubelskich przywilejów zwalniających miasto od ceł wynika jednak ze spostrzeżenia, że zabiegając o potwierdzenie ich przez Jagiełłę, rajcy nie przedstawili najważniejszego i najstarszego dokumentu, wcześniejszego od przywileju Łokietka ex Jatka Pacholonis. Mam na myśli przywilej lokacyjny Lublina z 1317, w którym zawarta jest przecież klauzula, dająca wieczyste zwolnienie wszystkich mieszkańców

${ }^{21}$ K. Myśliński, Wójt dziedziczny i rada miejska w Lublinie 1317-1504, Lublin 1962, s. 35-37.

${ }^{22}$ Kopia z XVIII w. APL DmL, sygn. 3; Od niedawna dostępna jest kopia internetowa kopii z APL: http://teatrnn.pl/lublinwdokumencie .

${ }^{23}$ Myśliński, Wójt dziedziczny, s. 35-37. 
miasta od ceł w całym państwie. Widocznie w 1405 r. nie znajdował się on wcale w archiwum miejskim, a był może poza Lublinem w posiadaniu wójtów (wyróżnienie moje A.M.- P.). Niemniej jego treść tak zasadniczej wagi, nie tylko dla wójtów, lecz także dla ogółu, powinna być kupcom lubelskim dobrze znana. Jeżeli nie powoływali się na niego w 1405 r. to chyba z pewnych względów. Stawiał on przecież pod znakiem zapytania autentyczność przywileju Łokietka ex Jatka Pacholonis, wydanego w zagadkowej miejscowości po 1320 r. Po cóż bowiem miałby Łokietek zaledwie kilka lat po wystawieniu przywileju lokacyjnego wydawać nowy przywilej, zwalniający mieszczan od ceł w całym państwie, skoro to samo uczynił w tamtym. Stawiał więc także pod znakiem zapytania autentyczność późniejszych przywilejów Elżbiety i Ludwika ${ }^{24}$.

Przywileje Elżbiety i Ludwika, podobnie jak dokument lokacyjny Władysława Łokietka z 1317 r. mogły się znajdować w posiadaniu wójtów i dlatego ocalały. Być może rajcy wiedzieli, gdzie one są, ale przemilczeli przed królem fakt ich istnienia nie $\mathrm{z}$ powodu ich nieautentyczności, ale z powodu rywalizacji o władzę $\mathrm{z}$ wójtami. Mając nowy dokument potwierdzający dawne przywileje, nie potrzebowali starszych. Taka argumentacja wydaje się wielce prawdopodobna i nie zmusza do negowania autentyczności wszystkich przywilejów wydanych przed 1405 r., które później pojawiły się w miejskim archiwum. Jak bowiem wskazują wspomniane wyżej kopiariusze i sumariusze, transumpt Elżbiety trafił tam później, i jeszcze w 1887 r., wedle informacji przekazanej przez Franciszka Piekosińskiego, przechowywany był w Archiwum Akt Dawnych w Lublinie ${ }^{25}$. Nie ulega bowiem wątpliwości, że jest to ten sam dokument, który uwzględniał wydawca Kodeksu Dyplomatycznego Małopolski. Jednakże po tym czasie z niewiadomych przyczyn zniknął z archiwum i gdy w 1938 r. Jan Riabinin publikował Materiały do historii miasta Lublina ${ }^{26}$, już go w archiwum nie znalazł, miał do dyspozycji jedynie kopię z XVIII w. przechowywaną w Magistracie Lubelskim oraz istniejące regesty w sumariuszach. Dokument nie mógł jednak znajdować się w archiwum, gdyż był już w tym czasie w posiadaniu rodziny Steckich. Notatka zamieszczona na odwrocie pergaminu z dnia 20 VIII 1917 r. potwierdza to ponad wszelką wątpliwość. Biblioteka KUL zakupiła go od Jana Steckiego 2 VI 1950 r., wkrótce potemzostałzaśopracowany bibliotecznieprzezAndrzeja Wojtkowskiego iumieszczony pod sygnaturą dypl. $38^{27}$. O obecności dokumentu w zbiorach rękopiśmiennych KUL badacze powojenni raczej nie wiedzieli, jak np. M. Trojanowska, która w opublikowanym przez siebie w roku 1996 Katalogu dokumentów miasta Lubli$n a$ również posłużyła się jedynie tą samą kopią i odpisami, co Riabinin. Cytowała przy tym zdanie K. Myślińskiego, że ,rzekomy oryginał wzmiankowany przez Piekosińskiego był późniejszym falsyfikatem"28, nie znała zaś sporządzonego w 1968 r. przez H. Mańkowską Katalogu dokumentów Biblioteki Uniwersyteckiej

${ }^{24}$ Tamże, s. 37.

${ }^{25} \mathrm{KDM}$, t. 3, s. 254.

${ }^{26}$ Riabinin, Materiaty do historii, nr 5, s. 3.

${ }^{27}$ Inwentarz dyplomów Biblioteki Uniwersyteckiej KUL, oprac. A. Wojtkowski, Lublin 19491950, k. 13 r. -13 v.

${ }^{28}$ Katalog dokumentów miasta Lublina, nr 3, s. 24. 
$K U L^{29}$, gdzie dokument był dokładnie opisany, a jego forma, treść, pismo, pieczęć i pozostałe cechy zewnętrzne nie wskazywały, by miał on być późniejszym falsyfikatem. Na istnienie dokumentu w zbiorach BU KUL zwracano uwage jeszcze dwukrotnie: w 2000 r. przypomniał o nim M. Butkiewicz ${ }^{30}$, a w 2004 Robert Sawa, który opublikował tekst oryginalny i przekład oraz przedstawił rozbiór dyplomatyczny dokumentu ${ }^{31}$. Niestety nadal jednak pojawiają się opracowania wskazujące, że osiemnastowieczna kopia przechowywana w APL jest jedyną zachowaną formą dokumentu. Tak sądzi dr Marcin Pytel, autor strony internetowej Lublin $w$ dokumencie:

Dokument Elżbiety Łokietkówny z $1371 \mathrm{r}$. dochował się do naszych czasów w XVIII - to wiecznej, nie uwierzytelnionej kopii. Jednakże jeszcze wydawca Kodeksu Dyplomatycznego Małopolski publikując omawiany dokument korzystał z oryginału. Kopia opisuje w sposób ogólny rodzaj pieczęci, który uwierzytelniał oryginalny dokument - mówi jedynie o przywieszonej pieczęci ${ }^{32}$.

W kontekście tej wypowiedzi i wcześniejszych wątpliwości Myślińskiego warto dodać, że nie ma powodu powątpiewać o autentyczności pieczęci Elżbiety Łokietkówny, gdyż wygląda identycznie ${ }^{33}$, jak pieczęć Elżbiety, którą uwierzytelnione są dwa dokumenty z 27 maja 1373 i 28 września 1379 r. ${ }^{34}$

\section{Dokument 2}

1376, 26 stycznia, Sandomierz

In Crastino Conversionis S. Pauli Apostoli Gloriosissimae. ment:

Ludwik król węgierski i polski zatwierdza i transumuje następujący doku-

1320, 13 maja - 1332, 2 maja, in Iatka Pacholonis.

Władysław [Łokietek] król polski zwalnia mieszczan lubelskich od wszelkich myt i opłat na drogach i w miastach królestwa polskiego.

Oryg., perg., j. łac., 31,5 x $21 \mathrm{~cm}$.

Pieczęci brak, ślad po przyszytym pasku pergaminowym, na którym była zawieszona pieczęć.

Na odwrocie pismem z XVI w.: Privilegium in quo continetur libertas a theoloneis in viis et civitatibus Regini Poloniae. Anno Domini 1376. Inną ręką: in Crastino Conversionis S. Pauli Nro 137, Nro 6to Lectum. Dalsze napisy zatarte i nieczytelne. Krótkie streszczenie dokumentu w języku polskim z 1917 r. sporządzone przez Jana Steckiego.

${ }^{29}$ Katalog dokumentów Biblioteki Uniwersyteckiej KUL, dok. nr 1, s. 7.

${ }^{30}$ Butkiewicz, Dyplomy w zbiorach, s. 77, 80-81);

${ }^{31}$ R. Sawa, Najstarszy dokument rękopiśmienny, w: Zbiory specjalne Biblioteki Uniwersyteckiej Katolickiego Uniwersytetu Lubelskiego, red. M. Trojnacka, Lublin 2004, s. 20-24.

${ }^{32} \mathrm{http}: / /$ teatrnn.pl/lublinwdokumencie/node/1

${ }^{33}$ Fotografia cyfrowa dokumentu dostępna na stronie: http://www.kul.pl/art_10787.html

${ }^{34} \mathrm{http}: / /$ dziedzictwo.polska.pl/katalog/skarb, ,gid,386449, cid,177.htm 
U dołu dokumentu pieczątka tuszowa, napis napieczętny brzmi: KSIĘGOZBIÓR ŁAŃCUCHOWSKI nr 666.

Stan zachowania dokumentu: dobry, ale pergamin jest obcięty u góry i dołu.

Ze zbioru łańcuchowskiego Jana Steckiego. Akcesja: 69/1950/k.

Bibl. KUL, sygn. dypl. 39.

Kolejny prezentowany tutaj dokument to wspominany już kilkakrotnie transumpt Ludwika Węgierskiego, poświadczający przywilej Władysława Łokietka, a wzmiankowany już w 1405 przez Władysława Jagiełłę. Jest to również oryginał, ale bez pieczęci, gdyż pergamin został obcięty u góry i pod tekstem, zachowały się nawet częściowo ślady mocowania pieczęci - znaki przyszycia pergaminowego paska, naktórym prawdopodobnie byłazawieszona. M. Butkiewicz podaje w wątpliwość ten rodzaj mocowania $\mathrm{w}$ XIV w. ${ }^{35}$, ale przecież przyszycie mogło nastąpić dużo później, co nie znaczy, że pieczęć była podrobiona. Dziś tego rozstrzygnąć nie sposób, jako że pieczęci nie było już wtedy, gdy F. Piekosiński publikował tekst dokumentu ${ }^{36}$. Ponadto warto w tym miejscu nadmienić, że w zbiorach KUL obok tego dokumentu jest załączona jego kopia z XVIII w. i co ciekawe, została ona sporządzona tą samą ręka, co kopia dokumentu Elżbiety Łokietkówny, znajdująca się w APL. Odpisy natomiast zachowały się w kopiariuszu z 1763 r. $^{37}$, a regesty w sumariuszach z 1781, 1819, 1836 i $1841 \mathrm{r}^{38}$. Nie ma zatem wątpliwości, że pochodzi z zasobów Archiwum Akt Dawnych w Lublinie, gdzie, wedle informacji przekazanej przez Franciszka Piekosińskiego ${ }^{39}$, przechowywany był jeszcze w 1886 i 1887 i że jest to ten sam dokument, który uwzględniał wydawca Kodeksu Dyplomatycznego Matopolski. Jan Riabinin podając regest tego dokumentu $^{40}$, podobnie jak w przypadku poprzedniego, już nie widział oryginału, lecz opierał się na wydaniu Piekosińskiego. Regest sporządził na podstawie odpisu zkopiariusza z 1763 r. przechowywanego w Archiwum Państwowym w Lublinie oraz istniejących regestów w sumariuszach. Dyplom ten Biblioteka KUL zakupiła od Jana Steckiego 2 VI 1950 r., wkrótce potem został opracowany bibliotecznie przez Andrzeja Wojtkowskiego i umieszczony pod sygnaturą dypl. $39^{41}$. Obecny jest w Katalogu Mańkowskiej ${ }^{42}$, na istnienie tego cennego dokumentu w zbiorach BU KUL nie zwracano dotąd uwagi, nie figuruje w katalogu M. Trojanowskiej (Archiwum nie ma bowiem jego luźnej kopii), w 2000 r. przypomniał o nim M. Butkiewicz ${ }^{43}$.

\footnotetext{
${ }^{35}$ Butkiewicz, Dyplomy w zbiorach, s. 81.

${ }^{36} \mathrm{KDM}$, t. 3, nr 880, s. 295-296.

${ }^{37}$ Kopiariusz z 1763 r., k. 18 r.

${ }^{38}$ Sumariusz z 1781 r. s. 2-3; sum. z 1819 r., nr 4; sum. z 1836 r. nr 4; sum. z 1841 nr 4.

${ }^{39} \mathrm{KDM}$, t. 2, s. 246 oraz KDM, t. 3, nr 880, s. 295-296.

${ }^{40}$ J. Riabinin, Materiaty do historii, dok. nr 6, s. 3-4

${ }^{41}$ Inwentarz dyplomów Biblioteki Uniwersyteckiej KUL, k. 13r.-13v.

${ }^{42}$ Katalog dokumentów Biblioteki Uniwersyteckiej KUL, dok. $\mathrm{nr}$ 2, s. 7-8.

${ }^{43}$ Butkiewicz, Dyplomy w zbiorach, s. 77, 80-81;
} 


\section{Dokument 3}

\section{9, 7 września, Piotrków 3 [co to?]}

Feria sexta in vigilia Nativitatis Glorissimae Virginis Mariae, in oppido Peotrkow in Conventione Generali pro festo Sancti Egidii abbatus celebrata.

Kazimierz [Jagiellończyk] król polski na sejmie piotrkowskim, w sporze pomiędzy rajcami miasta Lublina a archidiakonem lubelskim Klemensem z Przybysławic, przysądza dom przy kościele św. Michała archidiakonowi Klemensowi i jego następcom oraz zwalnia go od ciężarów i opłat, tak królewskich jak i miejskich.

Podpis podkanclerzego Jana Lutka z Brzezia.

Lista świadków.

Oryg., perg., j. łac., 41 x 23, 3 x 6, $3 \mathrm{~cm}$

Pieczęć Kazimierza Jagiellończyka (średnica $38 \mathrm{~mm}$ ) w czerwonym wosku w misce z wosku ciemnego, uszkodzona, zawieszona na jedwabnym, biało-czerwonym sznurku. Zob. Gumowski, Pieczęcie, tabl. XI nr 28.

$\mathrm{Na}$ odwrocie, pismem bardzo zatartym: 1459 Nro 103 Kazimiri Regis Libertatio areae Venerabilis Archidiaconi oraz pismem późniejszym krótka notatka podająca treść dokumentu, ponadto drugie streszczenie w języku polskim z 20 VIII 1917 r. sporządzone przez Jana Steckiego.

U góry dokumentu pieczątka tuszowa, napis napieczętny brzmi: KSIĘGOZBIÓR ŁAŃCUCHOWSKI nr 668.

Ze zbioru łańcuchowskiego Jana Steckiego. Akcesja: 69/1950/k.

Stan zachowania dokumentu: dobry. Dokument poddany konserwacji w 2003 r.

Bibl. KUL sygn. dypl. 40.

Jak wskazują sumariusze ${ }^{44}$ i J. A. Wadowski, niniejszy oryginał, należał jeszcze w 1907 r. ${ }^{45}$ do Akt Archiwum Dawnego Miasta Lublina, opisany przez niego jako „Przyw.[ilej] perg.[aminowy] w dobrym stanie z pieczęcią zachowany”, nie został jednak uwzględniony przez Riabinina, co oznacza że w 1938 r. już go w archiwum nie było. I nic dziwnego, streszczenie umieszczone na odwrocie dokumentu z datą 20 VIII 1917 r. sporządzone przez Jana Steckiego dowodzi, iż co najmniej od tego czasu dokument był w posiadaniu autora notatki. Biblioteka KUL zakupiła go od Jana Steckiego 2 VI 1950 r., wkrótce potem został opracowany bibliotecznie przez Andrzeja Wojtkowskiego i umieszczony pod sygnaturą dypl. $40^{46}$. Obecny jest w Katalogu Mańkowskiej ${ }^{47}$, na istnienie tego cennego dokumentu w zbiorach BU KUL nie zwracano dotąd uwagi, w 2000 r. przypomniał o nim jedynie M. Butkiewicz ${ }^{48}$.

\footnotetext{
${ }^{44}$ Reg.: sumariusz z 1781 r., s. 14; sum. z 1836 r. nr 33.

${ }^{45}$ Oprac.Wadowski, Kościoły lubelskie, s. 119.

${ }^{46}$ Wojtkowski, Inwentarz dyplomów, k. 14r.

${ }^{47}$ Mańkowska, Katalog dokumentów, dok. nr 4, s. 8.

${ }^{48}$ Butkiewicz, Dyplomy w zbiorach Biblioteki Uniwersyteckiej KUL, s. 79-80.
} 


\section{Dokument 4}

1460, 18 grudnia, Piotrków

Feria quinta ante festum Sancti Thomae apostoli proximae, Petricow.

Kazimierz [Jagiellończyk] król polski zatwierdza na sejmie piotrkowskim dotychczasowy zwyczaj odbywania sądów miejskich w Lublinie, bez przewodnictwa i udziału burgrabiego grodzkiego lub urzędnika starościńskiego za opłatą 1/2 grzywny co kwartał na utrzymanie zamku lubelskiego.

Oryg., perg., j. łac., 45,5 x 23,5 x 8,5 cm.

Pieczęć Kazimierza Jagiellończyka (średnica $48 \mathrm{~mm}$ ) w czerwonym wosku w misce z wosku ciemnego, na jedwabnym zielono-czerwono-białym sznurku, mocno uszkodzona. Zob. M. Gumowski, Pieczęcie królów polskich, zebrał i opisał i reprodukcjami światłodrukowemi opatrzył dr... Kraków 1910, tabl. 11 nr 27.

Na odwrocie krótkie streszczenia dokumentu z różnych czasów, ostatnie z 20 VIII 1917 r., napisane przez Jana Steckiego.

U góry dokumentu pieczątka tuszowa, napis napieczętny brzmi: KSIĘGOZBIÓR ŁAŃCUCHOWSKI nr 667.

Ze zbioru łańcuchowskiego Jana Steckiego. Akcesja: 69/1950/k.

Dokument poddano konserwacji w $2010 \mathrm{r}$.

Bibl. KUL sygn. dypl. 41.

Dokument ten jak trzy poprzednie, pochodzi z zasobów Archiwum Akt Dawnych w Lublinie. Potwierdzają to sumariusze z 1781, z 1836 i $1841^{49}$. Riabinin nie widział oryginału, ale zamieścił jego regest ${ }^{50}$ na podstawie odpisu z kopiariusza z $1763 \mathrm{r}^{51}$. Streszczenie sporządzone przez Jana Steckiego z datą 20 VIII $1917 \mathrm{r}$., umieszczone na odwrocie dokumentu, świadczy, że co najmniej od tego czasu był w jego posiadaniu. Biblioteka KUL zakupiła go od Jana Steckiego 2 VI 1950 r., wkrótce potem został opracowany bibliotecznie przez Andrzeja Wojtkowskiego i umieszczony pod sygnaturą dypl. $41^{52}$. Obecny jest w Katalogu Mańkowskiej ${ }^{53}$, na istnienie tego cennego dokumentu w zbiorach BU KUL nie zwracano dotąd uwagi, w 2000 r. przypomniał o nim jedynie M. Butkiewicz ${ }^{54}$.

\footnotetext{
${ }^{49}$ Reg.: sumariusz z 1781 r., s. 15; sum. z 1836 r. nr 35; sum. z 1841 r. nr 41.

${ }^{50}$ Riabinin, Materiały do historii, $\mathrm{nr}$ 49, s. 17.

${ }^{51}$ Odpis: kopiariusz z 1763 r., s. 8 v. -9 v.

${ }^{52}$ Inwentarz dyplomów Biblioteki Uniwersyteckiej KUL, k. 14 v.

${ }^{53}$ Katalog dokumentów Biblioteki Uniwersyteckiej KUL, dok. nr 5, s. 8-9.

${ }^{54}$ Butkiewicz, Dyplomy w zbiorach, s. 79-80.
} 


\section{Dokument 5}

1472, 19 czerwca, Koprzywinica

Die veneris decima nona mensis Iunii, Comprovnicae.

Mikołaj opat zakonu cystersów klasztoru w Koprzywnicy jako delegat papieski do sprawy objęcia kościoła parafialnego w Wąwolnicy i obsadzenia parafii przez zakonników klasztoru św. Krzyża na Łysej Górze, polecając opatowi klasztoru św. Krzyża, by wyznaczył jednego z zakonników na administratora parafii Wąwolnica, i wykonuje tym samym poniższą bullę papieską, którą jednocześnie transumuje i potwierdza :

\section{1, 19 czerwca, Rzym}

Tercio decimo Kalendas Iulii, Romae.

Papież Paweł II przychylając się do sugestii króla Kazimierza i próśb opata klasztoru benedyktynów św. Krzyża na Łysej Górze oraz biorąc pod uwagę zbyt szczupłe dochody wymienionego klasztoru, przyłącza doń i inkorporuje kościół parafialny w Wąwolnicy z całym uposażeniem i wydaje zlecenie, aby parafia była zarządzana przez zakonników wspomnianego klasztoru.

Oryg. (I. N.), perg., j. łac., 41 x 34,5 x 6 cm.

Pieczęć opata zakonu cystersów na jedwabnych niebiesko-zielono-białych sznurkach, w płóciennym woreczku, pokruszona.

Dokument poświadczony także znakiem notarialnym: Ego Jo. Petri lapideus creatus sum in Thabellionem 1466. Na odwrocie, pismem z XVII w. informacja o oblacie w aktach grodzkich krakowskich: Anno Domini 1646 die 18 Junii Cracoviae oblatum et ad Acta Illustrissimi et Reverendissimi Domini Petri Gembicki Dei et Apostolicae Sedis gratia Episcopi Cracoviensis introductum. Joannes Grabowski notarius. Inne napisy : Litterae super praepositurae in Wavelnicen. Executio Bullae.

Stan zachowania dokumentu: dobry. Poddany konserwacji w 2002 r.

Bibl. KUL sygn. dypl. 2.

Dokument pochodzi ze starych zasobów BU KUL. Jest jednym z pierwszych dyplomów opracowanych i skatalogowanych przez A. Wojtowskiego ${ }^{55} \mathrm{i}$ jak podaje H. Mańkowska ${ }^{56}$, mógł jak kilka innych, pojawić się w zbiorach KUL jeszcze w okresie międzywojennym i albo został wtedy włączony do zbiorów Biblioteki, albo znajdował się w muzeum uniwersyteckim, zaś po wojnie odnaleziony, został przekazany Bibliotece do właściwego przechowania i opracowania. Mimo obecności regestu dokumentu w Katalogu Mańkowskiej ${ }^{57}$, przez dłuższy czas pozostawał niezauważony. Dopiero w 2000 M. Butkiewicz poświęcił mu osobny artykuł ${ }^{58}$

${ }^{55}$ Wojtkowski, Inwentarz dyplomów., k. 2 r.

${ }^{56}$ Mańkowska, Katalog dokumentów, s. 5.

${ }^{57}$ Mańkowska, Katalog dokumentów, dok. nr 6, s. 9. Uwaga: U Mańkowskiej błędna data : 19 czerwca 1742 (wynikająca z zamiany kolejności cyfr w dacie rocznej).

${ }^{58}$ M. Butkiewicz, Średniowieczny dokument w zbiorach Biblioteki Uniwersyteckiej KUL dotyczący dziejów benedyktynów na Lubelszczyźnie, w: Klasztor na Świętym Krzyżu w polskiej kul- 
i oraz krótką wzmiankę w innym ${ }^{59}$, pragnąc zwrócić uwagę na ten cenny dla badaczy dziejów Lubelszczyzny dokument. Nadmienił, że mimo opublikowania jego regestu w Katalogu Mańkowskiej, dokument został pominięty w Słowniku historyczno-geograficznym województwa lubelskiego w średniowieczu, opracowanym przez Stanisława Kurasia, który podaje informację o bulli na podstawie oblaty w aktach krakowskich sporządzonej w $1646 \mathrm{r}^{60}$ ( informacje o tej oblacie znajdują się na odwrocie dokumentu ${ }^{61}$. Niestety brak wiedzy o tym dokumencie współczesnych badaczy nadal jest faktem i skutkuje tym, iż w Bullarum Poloniae, t. 7 jest tylko krótka wzmianka na temat bulli Pawła II na podstawie Registra Lateranensa (nr 670, f. 280), podczas dokument ze zbiorów KUL nie został uwzględniony ${ }^{62}$.

\section{Dokument 6}

1486, 10 maja, Kraków

Feria quarta post festum Stanislai sancti proxima, Cracoviae.

Rajcy sześciu miast: Krakowa, Sącza, Kazimierza, Wieliczki, Bochni i Olkusza w sprawie obywateli lubelskich Jakuba Kreydlera przeciwko Janowi Ordynce Szydłowieckiemu o czynsz z 8 ogrodów za miastem postanawia, iż Ordynka, o ile nie będzie płacił Kreydlerowi z każdego ogrodu regularnie co rok 2 grzywny, utraci na zawsze prawo dzierżawy.

Podpisów brak.

Lista świadków.

Oryg., perg., j. łac., 33 x 25,5 x 3,7 cm.

Pieczęć rady miejskiej Kazimierza, woskowa, uszkodzona, zawieszona na pergaminowym pasku. Pieczęci innych miast brak, pozostały 2 paski i 3 nacięcia na paski.

Na odwrocie mało czytelne streszczenie dokumentu.

Po lewej stronie dokumentu pieczątka tuszowa, napis napieczętny brzmi: KSIĘGOZBIÓR ŁAŃCUCHOWSKI nr 669.

Ze zbioru łańcuchowskiego Jana Steckiego. Akcesja: 69/1950/k.

Stan zachowania dokumentu: dobry. Dokument poddano konserwacji w 2003 r.

Bibl. KUL sygn. dypl. 42.

Dokument pochodzi z zasobów Archiwum Akt Dawnych w Lublinie, gdzie, jak wskazują sumariusze, był jeszcze w 1841 r. Jan Riabinin, już nie widział ory-

turze narodowej, red D. Olszewski R. Grycz, Kielce 2000, s. 325-329.

${ }^{59}$ Butkiewicz, Dyplomy w zbiorach Biblioteki Uniwersyteckiej KUL, s. 77-78.

${ }^{60}$ Por. Słownik historyczno-geograficzny województwa lubelskiego w średniowieczu, oprac. S.

Kuraś, w: Dzieje Lubelszczyzny, t. 3, Warszawa 1983, s. 254.

${ }^{61}$ Zob. Butkiewicz, Średniowieczny dokument, s. 328

${ }^{62}$ Por. Bullarum Poloniae, t. 7, ed. I. Sułkowska-Kuraś, S. Kuraś, Romae-Lublin 2006, nr 914, s. 277. 
ginału, lecz opierał się na istniejących regestach w sumariuszach ${ }^{63}$. W sumariuszu z 1781 r. omyłkowo zapisano dokument pod datą 1476 - na marginesie ktoś (Riabinin?) zaznaczył ołówkiem: „1486?”. U Rabinina wystawca został błędnie określony jako „radni zamku krakowskiego" ${ }^{64}$, zapewnie z powodu błędów zawartych w sumariuszach.

Biblioteka KUL zakupiła go od Jana Steckiego 2 VI 1950 r., wkrótce potem został zaś opracowany bibliotecznie przez Andrzeja Wojtkowskiego i umieszczony pod sygnaturą dypl. $42^{65}$. Obecny jest w Katalogu Mańkowskiej ${ }^{66}$, na istnienie tego cennego dokumentu w zbiorach BU KUL nie zwracano dotąd uwagi, krótką wzmiankę uczynił na jego temat uczynił jedynie M. Butkiewicz ${ }^{67}$.

\section{Dokument 7}

1499, 15 kwietnia, Lublin

Feria secunda proxima post festum sancti Tiburtii, Lublini.

Piotr Firlej z Dąbrowicy (de Dambrowicza) sędzia ziemski lubelski i Piotr Pszonka z Babina (de Babin), podsędek lubelski zaświadczają, że Łukasz Kaszowski [syn Mikołaja] zapisuje swojej żonie Urszuli [Sienickiej], córce Jana z Sienna [de Siennicza], czterysta grzywien na swoich dobrach Wysokie zabezpieczając na tych dobrach jej wiano w kwocie 200 grzywien i przywianek w kwocie 200 grzywien.

Podpis własnoręczny pisarza ziemskiego lubelskiego Mikołaja [z Kijan].

Lista świadków.

Oryg., perg., j. łac., 26,5 x 17,5 x $3 \mathrm{~cm}$.

Pieczęć Piotra Pszonki odciśnięta w ciemnym wosku z herbem Janina, słabo czytelna, przytwierdzona pergaminowym paskiem, ślad po drugiej pieczęci po lewej stronie dokumentu, była pieczęcią Piotra Firleja. W koroboracji informacja, że oprócz pieczęci Piotra Pszonki była tam także pieczęć Piotra Firleja.

Stan zachowania dokumentu: dobry. Poddany konserwacji w 2004 r. Przechowywany w specjalnym pudle sporządzonym przez konserwatora.

Bibl. KUL sygn. dypl. 90.

Dokument jest bardzo cenny dla dziejów Lubelszczyzny, lecz nie znany w literaturze naukowej. Brak informacji o nim w zachowanych księgach ziemskich lubelskich, które znajdują się w Archiwum Państwowym w Lublinie. Poświadczony akt prawny został odnotowany w Metryce Koronnej ${ }^{68}$. Nie cytowany

${ }^{63}$ Sumariusz z 1781 r., s. 17; sum. z 1836 nr 44; sum. z 1841 r., nr 50.

${ }^{64}$ Riabinin, Materiały do historii, nr 63, s. 21.

${ }^{65}$ Wojtkowski, Inwentarz Dyplomów, k. 14 v-15 r.;

${ }^{66}$ Mańkowska, Katalog dokumentów, dok. nr 7, s. 9. Uwaga: U A. Wojtkowskiego i H. Mańkowskiej błędna data $11 \mathrm{~V} 1486$ zamiast $10 \mathrm{~V} 1486 \mathrm{r}$.

${ }^{67}$ Butkiewicz, Dyplomy w zbiorach Biblioteki Uniwersyteckiej KUL, s. 77.

${ }^{68}$ MK 24, k. 57, 58. 
w opracowaniach powojennych.

Nie znaleziono także informacji, by jacyś badacze z niego korzystali. Biblioteka KUL zakupiła go od Zygmunta Nowakowskiego z Puław w 1973 r. Do roku 2004 dokument pozostawał w zbiorach nieopracowanych BU KUL ${ }^{69}$.

\section{Dokument 8}

1503, 28 listopada, Lublin

Feria tertia proxima ante festum sancti Andreae Apostoli, Lublini.

Aleksander [Jagiellończyk] król polski pozwala miastu Lublinowi wybrać z czopowego 300 florenów, pożyczonych królowi na wyprawę wojenną, a nadto, po wybraniu tej sumy, zwalnia miasto od czopowego na dalsze trzy lata.

Podpis własnoręczny kanclerza wielkiego koronnego Jana Łaskiego.

Oryg., perg., j. łac., 34,5 x 14,7 x 5 cm.

Pieczęć wielka koronna Aleksandra Jagiellończyka (średnica $73 \mathrm{~mm}$ ), woskowa, zawieszona na pergaminowym pasku, uszkodzona. Zob. Gumowski, Pieczęcie..., tabl. $12 \mathrm{nr} 38$; Żebrawski, O pieczęciach, tabl. $20 \mathrm{nr} 64$.

$\mathrm{Na}$ odwrocie krótkie streszczenie dokumentu w j. łacińskim oraz polskie sporządzone przez Jana Steckiego 5 IX 1917 r. (treść jak w powyższym regeście).

Na marginesie po lewej stronie dokumentu pieczątka tuszowa, napis napieczętny brzmi: KSIĘGOZBIÓR ŁAŃCUCHOWSKI nr 671.

Stan zachowania dokumentu: dobry.

Ze zbioru łańcuchowskiego Jana Steckiego. Akcesja 69/1950/k.

Bibl. KUL sygn. dypl. 43.

Dokument pochodzi z zasobów Archiwum Akt Dawnych w Lublinie, gdzie, jak wskazują sumariusze, był jeszcze w 1841 r. ${ }^{70}$. Widnieje też w Sumariuszu Metryki Koronnej ${ }^{71}$, ale zapewne znany był wydawcom na podstawie regestów, gdyż istnieje drobna pomyłka w dacie 21 XI zamiast 28 XI. Jan Riabinin, już nie widział oryginału, lecz opierał się na istniejących regestach w sumariuszach ${ }^{72}$. Prawdopodobnie $\mathrm{z}$ powodu błędów w regestach także $\mathrm{u}$ niego jest błędna data 21 XI 1503. Jak wskazuje zamieszczone na odwrocie streszczenie, 5 IX 1917 r. dokument był w posiadaniu Jana Steckiego. Biblioteka KUL zakupiła go od Jana Steckiego 2 VI 1950 r., wkrótce potem został opracowany bibliotecznie przez Andrzeja Wojtkowskiego i umieszczony pod sygnaturą dypl. $43^{73}$. Obecny jest w Katalogu Mańkowskiej ${ }^{74}$, na istnienie tego cennego dokumentu w zbiorach BU KUL nie zwracano dotąd uwagi.

\footnotetext{
${ }^{69}$ Fotografia cyfrowa dokumentu dostępna na stronie: http://www.kul.pl/art_10787.html

${ }^{70}$ Sumariusz z 1781 r. s. 21; sum. z 1819 r. nr 120, z 1836 r. nr 52, z 1841 nr 58.

${ }^{71}$ MRPS, t. 3, Warszawa 1874, nr 981, s. 61.

${ }^{72}$ Riabinin, Materiały do historii, nr 82, s. 26.

${ }^{73}$ Inwentarz dyplomów Biblioteki Uniwersyteckiej KUL, k. 15 r.-15 v.

${ }^{74}$ Katalog dokumentów Biblioteki Uniwersyteckiej KUL, dok. nr 9, s. 10.
} 
1532, 16 marca, Krasnystaw

\section{Dokument 9}

Sabbato proximo ante Dominicam Iudica, in castro Crasnostaviensi.

Andrzej z Tęczyna wojewoda krakowski i Jan z Tęczyna wojewoda bełzki, widymuje i potwierdza na podstawie akt grodzkich i starościńskich krasnostawskich poniższy dokument:

1531, 20 listopada, Krasnystaw

Feria secunda post festum sanctae Elisabeth, in castro Crasnostaviensi.

Andrzej z Tęczyna wojewoda krakowski i Jan z Tęczyna wojewoda bełzki dają zezwolenie, by Anna Ciołkowa sprzedała dominikanom obserwantom w Lublinie swoją część dóbr Łańcuchowo z przynależnymi wsiami za sumę 400 zł, z prawem wykupu.

Podpisów brak.

Oryg., perg., j. łac., 40 x 26,3 x $4 \mathrm{~cm}$.

Pieczęci brak, pozostał pergaminowy pasek.

$\mathrm{Na}$ odwrocie nota o oblacie w grodzie krasnostawskim oraz streszczenie dokumentu.

Na marginesie po lewej stronie dokumentu pieczątka tuszowa, napis napieczętny brzmi: KSIĘGOZBIÓR ŁAŃCUCHOWSKI nr 93.

Ze zbioru łańcuchowskiego Jana Steckiego. Akcesja 69/1950/k.

Bibl. KUL sygn. dypl. 44.

Jak wskazują znaki proweniencyjne, dokument był w posiadaniu Jana Steckiego. Biblioteka KUL zakupiła go od niego 2 VI 1950 r., wkrótce potem został zaś opracowany bibliotecznie przez Andrzeja Wojtkowskiego i umieszczony pod sygnaturą dypl. $44^{75}$. Obecny jest w Katalogu Mańkowskiej ${ }^{76}$, na istnienie tego cennego dokumentu w zbiorach BU KUL nie zwracano dotąd uwagi.

\section{Dokument 10}

1543, [30] sierpnia, Kock.

Po świętym Bartlomieju blisko przesztym, na zamku w Kocku.

Piotr Firlej z Dąbrowicy wojewoda lubelski lokuje na gruntach wsi Szczekarków miasto Lewartów (dziś Lubartów) na prawie magdeburskim, ustala różnorodne prawa i przywileje dla odpowiedniego funkcjonowania miasta, $\mathrm{m}$. in. na swobodne wycinanie drzew na potrzeby budownictwa, pozwolenie na stoły rzeźnicze $\mathrm{i}$ handel mięsem wielkim i małym we wtorki w mieście Lewartowie $\mathrm{z}$ koniecznością uiszczania Piotrowi Firlejowi i jego potomkom podatku zwanego targowym według zwyczaju, który panuje w Kocku. Uwalnia też miasteczko od wszelkich sądów świeckich, przenosząc je bezpośrednio pod jurysdykcję Firlejów i ich potomków. Ustanawia więzienie miejskie dla pospolitych przestępców i na-

\footnotetext{
${ }^{75}$ Wojtkowski, Inwentarz Dyplomów, k. 15 v.

${ }^{76}$ Mańkowska, Katalog dokumentów, dok. nr 10, s. 10.
} 
kazuje sądzić ich według prawa miejskiego, z wyjątkiem bardzo ciężkich przestępstw jak złodziejstwo i mężobójstwo. Ponadto ustanawia dla wszystkich mieszkańców Lewartowa podatek od każdego łana po 24 grosze, z ogrodów po 2 grosze, z folwarków po 20 groszy, dając przy tym 24 lata wolnizny od powinności na rzecz dworu.

Kopia nie uwierzytelniona, perg., j. pol., XVII w., 45,5 x $29 \mathrm{~cm}$. Dokument starannie przepisany, inwokacja majuskułą, inicjał delikatnie zdobiony, brzegi dokumentu zdobione bordiurą, pismo: kursywa humanistyczna XVII wiek, dokument niewykończony.

Pieczęci brak. W koroboracji jest mowa o zawieszonej pieczęci Piotra Firleja, ale brak jakichkolwiek śladów jej mocowania.

Na odwrocie: 1543 po $S$. Bar. oraz dawne numery archiwalne.

Stan zachowania dokumentu: bardzo dobry. Poddany konserwacji w 2004 r. Przechowywany w specjalnym pudle sporządzonym przez konserwatora.

Bibl. KUL sygn. dypl. 104.

Jest to przełożona na język polski kopia (oryg. zaginął) przywileju lokacyjnego dla Lewartowa, nadanego przez Piotra Firleja z Dąbrowicy wojewodę lubelskiego [zm. 1553] wkrótce po zezwoleniu na lokację Lewartowa na prawie magdeburskim, wydanym przez Zygmunta I Starego 29 maja $1543^{77}$. Kopia ta jest późniejsza od oryginału, powstała ok. początku XVII stulecia, prawdopodobnie na użytek mieszczan, gdyż łacina mimo powszechności użycia, dla ludzi niewykształconych była przecież niezrozumiała. Kopia przez wieki pozostawała w posiadaniu cechmistrzów lubartowskich. Prawdopodobnie leżała z aktami cechu żelaznego w Lubartowie, wśród których znajdowała się przełożona na język polski osiemnastowieczna kopia przywileju lokacyjnego Lubartowa. Na podstawie omawianej w tym miejscu siedemnastowiecznej kopii, jeden z badaczy lubelskich (z pewnością doświadczony historyk) sporządził na początku XX w. kopię tego dokumentu i opatrzył ją komentarzem.

Dokument spisany na pergaminie, pieczęci nie ma. Sądząc z charakteru pisma i ortografii twierdzę, że musi to być odpis oryginału o kilkadziesiąt lat starszego. Na zewnętrznej czystej stronie perg. „1543 po S. Bar.: oraz numera i znaki archiwalne.

Opis ten w pełni zgadza się z pergaminem przechowywanym w Bibliotece KUL. Natomiast ta papierowa kopia obecnie przechowana jest w Archiwum Pań-

${ }^{77}$ Por. Katalog dokumentów Archiwum Państwowego w Lublinie, cz. 2: Katalog dokumentów różnej proweniencji miast, wsi, cechów, parafi, klasztorów i osób prywatnych, oprac. M. Trojanowska, Lublin 1998 (cyt. dalej jako Katalog dokumentów różnej proweniencji), dok. nr 18, s. 28 (regest na podstawie kopii z 1743 r., będącej tłumaczeniem oryginału łacińskiego, Akta cechu żelaznego w Lubartowie, sygn. 1. Kopia tego pierwszego przywileju jest też dostępna w wersji internetowej: http://dziedzictwo.polska.pl/katalog/skarb,Zezwolenie_na_zalozenie_miasta_Lewartow_i_nadanie_miastu_prawa_magdeburskiego_29_V_1543_r,gid,330660,cid,5386.htm 
stwowym w Lublinie ${ }^{78}$, ale początkowo była w posiadaniu Biblioteki Łopacińskiego pod syg. rkps 178, o czym świadczy nota w katalogu Aleksandra Jaworowskiego $^{79}$. Opis dokumentu nr 178 z Biblioteki Łopacińskiego sporządzony przez A. Jaworowskiego jest wprawdzie bardzo lakoniczny, ale z dużą pewnością można przyjąć, że chodziło o papierową kopię dwudziestowieczną, a nie o pergamin z XVII w., gdyż później dokument zastąpiono mikrofilmem z tej samej dwudziestowiecznej kopii ${ }^{80}$, która została przeniesiona do Archiwum Państwowego w Lublinie w miejsce zaginionej pergaminowej siedemnastowiecznej kopii, ta zaś jak wiemy, odnalazła się dopiero w 2004 r. w nie opracowanych zbiorach rękopiśmiennych Biblioteki KUL. W 1932 r. dokument został opublikowany przez Zofię Rościszewską w pracy Lewartów (Lubartów) w latach 1543-1643 $3^{81}$. Poświadczyła, że drukowała go, podobnie jak dokument wydany przez Zygmunta I $29 \mathrm{~V}$ $1543 \mathrm{r}^{82}$, na podstawie dokumentów rękopiśmiennych znajdujących się w posiadaniu cechmistrzów lubartowskich. Przy publikacji przywileju Zygmunta korzystała zatem ze wspomnianej wyżej osiemnastowiecznej kopii, a w przypadku przywileju Piotra Firleja z omawianej tutaj siedemnastowiecznej kopii spisanej na pergaminie. Potwierdza to tezę, że jeszcze na początku lat trzydziestych XX w. oba przywileje lubartowskie były, jak wspomniano wyżej, przechowywane przez cechmistrzów lubartowskich i przedwojenni badacze historii Lubartowa dobrze je znali ${ }^{83}$. Obecnie większość dokumentów cechów lubartowskich znajduje się w Archiwum Państwowym w Lublinie. Trafiły tam w czasie okupacji hitlerowskiej na rozkaz władz niemieckich. W zgromadzonych wówczas przez archiwum dokumentach nie było już jednak przywileju wydanego przez Piotra Firleja. Dla badaczy pozostała tylko papierowa kopia z XX w., przeniesiona do archiwum z Biblioteki Łopacińskiego oraz druk Rościszewskiej. Na ich podstawie powstało opracowanie Stanisława Tworka ${ }^{84}$ oraz regest w Katalogu dokumentów różnej proweniencji Marii Trojanowskiej ${ }^{85}$. Jako że Trojanowska korzystała z kopii dwudziestowiecznej, wiedziała na podstawie zawartej tam adnotacji, że jest przepisana z pergaminowej kopii ${ }^{86}$, sądziła jednak, iż Rościszewska opierała na oryginale ${ }^{87}$,

${ }^{78}$ APL, Dokumenty miasta Lubartowa, sygn. 1. Ponadto kopia internetowa kopii z APL: http:// dziedzictwo.polska.pl/katalog/skarb,Nadanie_praw_mieszkancom_Lewartowa_25_VIII_1543_ r,gid,330758,cid,5386.htm

${ }^{79}$ Katalog rękopisów Biblioteki Publicznej im. H. Łopacińskiego, rkps nr 178, s. 19.

${ }^{80}$ Biblioteka im. H. Łopacińskiego posiada mikrofilm negatywowy kopii znajdującej się w APL: Mf 361 (19 neg. Fotogr. 484/12).

${ }^{81}$ Z. Rościszewska, Lewartów (Lubartów) w latach 1543-1643, Lublin 1932. Druk w dodatku źródłowym według pisowni zmodernizowanej, s. 45-47, informacja o rękopisie we wstępie, s. 7.

${ }^{82}$ Tamże, druk w dodatku źródłowym według pisowni zmodernizowanej, s. 42-45, informacja o rękopisie we wstępie, s. 7.

${ }^{83}$ W. J. Śliwina, F. Tracz, Ziemia Lubartowska. Szkic monograficzny, ilustrowany, Lubartów 1928, s. 59-60;

${ }^{84} \mathrm{~S}$. Tworek, Narodziny i rozwój miasta w latach 1543-1660, w: Lubartów z dziejów miasta $i$ regionu, red. S. Tworek, Lublin 1977, s. 11-24.

${ }^{85}$ Reg.: Katalog dokumentów różnej proweniencji, dok. nr 19, s. 28-29.

${ }^{86}$ Tamże, s. 28.

${ }^{87}$ Tamże,s. 29. 
podczas gdy zarówno kopia przechowywana w archiwum, jak i druk Rościszewskiej opierały się na tej samej siedemnastowiecznej kopii. Pomyłka ta skutkowała także mylnym przypuszczeniem M. Trojanowskiej, że Rościszewska, określając datę wystawienia dokumentu na 25 VIII 1543, miała wiedzę co do dnia tygodnia, a autor dwudziestowiecznej kopii pominą ją przypadkowo ${ }^{88}$. W istocie w siedemnastowiecznej kopii również nie podano dnia tygodnia i Rościszewska zinterpretowała określenie „Po świętym Barttomieju blisko przesztym” właśnie jako 25 VIII (święto św. Bartłomieja przypadało na 24 VIII). Według ustaleń profesora Ryszarda Szczygła, prawdziwą datą oryginału jest 30 VIII 1543 r. (Feria quinta post festum S. Bartolomei), co wiadomo na podstawie transumptu Augusta III z 22 listopada 1744 r., w którym August odnawia przywileje miejskie dla Lubartowa. Transumpt ten przechowywany jest w Archiwum Państwowym w Krakowie (Archiwum Sanguszków, perg. nr 306$)^{89}$. Profesor R. Szczygieł nie wiedząc o zachowanej w BU KUL siedemnastowiecznej kopii przywileju Firleja, wyraził zdziwienie, że w Katalogu różnej proweniencji opracownym przez M. Trojanowską ,podano datę za Rościszewską, chociaż zamieszczono uwagę, że kopista pominął datę dzienną" ${ }^{\circ}$. Powyższe rozważania wyjaśniają jednak dokładnie, skąd się wzięła ta nieścisłość.

\section{Dokument 11}

1554, 20 marca, Lublin

Feria tertia post Dominicam Palmarum, Lublini.

Zygmunt August król polski transumuje i potwierdza dokument następującej treści:

1553, 5 maja, Kraków

Feria sexta post Dominicam Cantate proxima. treści:

Zygmunt August król polski transumuje i potwierdza dokument następującej

1553, 28 kwietnia, Lublin

Feria sexta post festum sancti Adalberti proxima, Lublini.

Piotr Firlej wojewoda ruski rozstrzyga spór graniczny między dobrami królewskimi Koczergi, przedmieściem Parczowa oraz wsiami Cichostów, Okalew, Zminna i Milkow, będącymi tenutą Stanisława Tęczyńskiego wojewody smoleńskiego, starosty lubelskiego i bełzkiego, należącymi do miasta Parczowa z jednej strony, a wsią Glinnystok, należącą do Jana Ryszkowskiego, z drugiej strony.

${ }^{88}$ Tamże, s. 29.

${ }^{89}$ R. Szczygieł, Odnowienie prawa miejskiego miasta Lubartowa z 1744 roku, w: Religie. Edukacja. Kultura. Księga pamiątkowa dedykowana profesorowi Stanisławowi Litakowi, red. M. Surdacki, Lublin 2002, s. 608-609 (cały artykuł: s, 607-612).

${ }^{90}$ Tamże, s. 609. 
Podpis własnoręczny kanclerza wielkiego koronnego Jana Ocieskiego.

Oryg., perg., j. łac., 85,8 x 56,6 x 13,2 cm.

Pieczęć wielka koronna Zygmunta Augusta (średnica $87 \mathrm{~mm}$ ) w czerwonym wosku, uszkodzona, zawieszona na jedwabnym zielono-czerwono-białym sznurku. Zob. Gumowski, Pieczęcie..., tabl. XIV nr 50.

Na odwrocie: Sigismundus Augustus Datum Lublini Feria tercia post Dominicam Palmarum Anno Domini 1554. Regni Nostri 25. A. 14.

Na górze dokumentu pieczątka tuszowa, napis napieczętny brzmi: KSIĘGOZBIÓR ŁAŃCUCHOWSKI nr 568 .

Ze zbioru łańcuchowskiego Jana Steckiego.

Akcesja 63/1950/k.

Stan zachowania dokumentu: zły. Dokument poddano konserwacji w 2010 r.

Bibl.KUL sygn. dypl. 45.

Jak wskazują znaki proweniencyjne, dokument był w posiadaniu Jana Steckiego. Nie wiadomo jaka jest jego wcześniejsza proweniencja, nie notują go sumariusze Archiwum Akt Dawnych w Lublinie. Obecny jest natomiast w sumariuszu Metryki Kororonnej ale pod datą 20 III 155691. Biblioteka KUL zakupiła go od Steckiego 2 VI 1950 r., wkrótce potem został opracowany bibliotecznie przez Andrzeja Wojtkowskiego i umieszczony pod sygnaturą dypl. $45^{92}$. Obecny jest w Katalogu Mańkowskiej ${ }^{93}$, na istnienie tego cennego dokumentu w zbiorach BU KUL nie zwracano dotąd uwagi.

\section{Dokument 12}

1570, 26 czerwca, Warszawa

W poniedziałek po świętym Janie Krzcicielu, w Warszawie na Sejmie walnym koronnym.

Zygmunt August król polski potwierdza przywilej nadany mieszczanom lubelskim przez króla Władysława [Łokietka], potwierdzony także przez innych polskich królów, a zwalniający ich od ceł i myt na obszarze całego królestwa, i rozszerza go na obszar całego Wielkiego Księstwa Litewskiego oraz na ziemie przyłączone do Korony na sejmie lubelskim w 1569 r., a mianowicie: ziemię kijowską, wołyńską i podlaską, za wyjątkiem nowego cła pogranicznego przeznaczając je dla siebie i swoich następców.

Podpis własnoręczny kanclerza wielkiego koronnego Walentego Dembińskiego.

Oryg., perg., j. pol., 46, 5 x 30,2 x 7, $6 \mathrm{~cm}$.

Dokument z ozdobnym inicjałem.

\footnotetext{
${ }^{91}$ MRPS, t. 5, cz. 1, nr 1782, s. 112.

${ }^{92}$ Wojtkowski, Inwentarz Dyplomów, k. 16 r.

${ }^{93}$ Mańkowska, Katalog dokumentów, dok. nr 11, s. 10.
} 
Pieczęć wielka koronna Zygmunta Augusta, w czerwonym wosku w misce z wosku ciemnego obszytej skórą, zawieszona na jedwabnym niebiesko-czerwono-zielonym sznurku, nieznacznie uszkodzona. Zob. Gumowski, Pieczęcie..., tabl. 14 nr 50. Żebrawski, O pieczęciach, tabl. $21 \mathrm{nr}$ 76.

U dołu napis w języku tureckim. Na odwrocie nieczytelne i zatarte streszczenia dokumentu z XVII w. oraz streszczenie w j. polskim z 20 VIII 1917 r. sporządzone przez Jana Steckiego.

Na marginesie po lewej stronie dokumentu pieczątka tuszowa, napis napieczętny brzmi: KSIĘGOZBIÓR ŁAŃCUCHOWSKI nr 672.

Stan zachowania dokumentu: dobry. Poddany konserwacji w 2003 r. Przechowywany w specjalnym pudle sporządzonym przez konserwatora.

Ze zbioru łańcuchowskiego Jana Steckiego. Akcesja 63/1950/k.

Bibl. KUL, sygn. dypl. 46.

Dokument pochodzi $\mathrm{z}$ dawnych zasobów archiwum miejskiego w Lublinie, gdzie, jak wskazuje kopiariusz był jeszcze w $1751^{94}$, potwierdzają go również sumariusze z 1781, 1819, 1836 i $1841^{95}$ Jan Riabinin już nie widział oryginału, lecz opierał się na zachowanej kopii z XVIII w. ${ }^{96}$ oraz na istniejących regestach w sumariuszach. Maria Trojanowska również nie znała oryginału, uwzględniła jednak dokument w Katalogu, mając do dyspozycji wzmiankowaną kopię papierową ${ }^{97}$. Biblioteka KUL zakupiła pergaminowy dokument od Jana Steckiego 2 VI 1950 r., wkrótce potem został opracowany bibliotecznie przez Andrzeja Wojtkowskiego i umieszczony pod sygnaturą dypl. $46^{98}$. Obecny jest w Katalogu Heleny Mańkowskiej ${ }^{99}$, na istnienie tego cennego dokumentu w zbiorach BU KUL nie zwracano dotąd uwagi, choć jest przecież potwierdzeniem i kontynuacją przywileju Władysława Łokietka oraz jego transumptów wydanych przez Elżbietę Łokietkównę i Ludwika Węgierskiego.

\section{Dokument 13}

1595, 8 grudnia, Kraków

Die octava mensis Decembris, Cracoviae.

Zygmunt III król polski zatwierdza i transumuje dokument następującej treści:

1595, 14 wrzesień, Lublin

Jan Firlej podskarbi wielki koronny i starosta lubelski zatwierdza statut cechu piekarzy na Podzamczu Lubelskim.

Podpis naśladowany Sigismundus Rex oraz podpis własnoręczny Stanisława

\footnotetext{
${ }^{94}$ Odpis: kopiariusz 1751 r., nr 13.

${ }^{95}$ Reg: sumariusz z 1781r., s. 38, z 1819 r. nr 115, z 1836 r. nr 128, z 1841 nr 148.

${ }^{96}$ APL, DmL sygn. 117 (sygnatura obecna, dawniejsza sygnatura nr 103).

${ }^{97}$ Katalog dokumentów miasta Lublina, nr 128, s. 84.

${ }^{98}$ Inwentarz dyplomów Biblioteki Uniwersyteckiej KUL, k. 16r-16v.;

${ }^{99}$ Katalog dokumentów Biblioteki Uniwersyteckiej KUL, dok. nr 12, s. 10-11.
} 
W. Kochlewskiego (bez tytulacji).

Oryg., perg., j. łac. i pol., 58 x 37,8 x 3,8 cm.

Pieczęci brak, zostały nacięcia na sznurki.

$\mathrm{Na}$ odwrocie streszczenie dokumentu w j. łacińskim z XVII w. oraz pismem XVII-to wiecznym: Przywiley Podzameckim Piekarzom stużacy. Nro 2-do.

Dokument niewykończony. Brak ozdobnie wypisanego imienia króla Sigismundus. Tekst zaczyna się od wyrazu Tertius.

Akcesja rkp 102/1950.

Stan zachowania dokumentu: dobry.

Bibl.KUL sygn. dypl. 68.

Dokument pochodzi z zasobów cechu piekarskiego w Lublinie, jeszcze około 1932 roku znajdował się w skrzynce cechowej pod opieką cechmistrzów, natomiast z pewnością nie było go tam już w czasie niemieckiej okupacji. Jak bowiem podaje Maria Stankowa we wstępie do Inwentarza Zespotu akt Cechy Lublina i Lubelszczyzny, władze niemieckie nakazały lubelskim cechom przekazanie wszystkich dokumentów cechowych do Archiwum Państwowego: „W okresie okupacji hitlerowskiej, archiwalne władze niemieckie, w ramach akcji zabezpieczenia archiwaliów zaczęły odbierać akta cechowe z rąk cechów. Dzięki tej akcji WAP Lublin znalazł się w posiadaniu dość pokaźnej ich liczby. Niestety nie wszystkie cechy oddały posiadane dokumenty, niektóre w obawie przed Niemcami ukryły posiadane akta, powodując $\mathrm{w}$ ten sposób ich zniszczenie ${ }^{100}$. Wśród zabezpieczonych przez władze niemieckie dokumentów cechu piekarskiego tego przywileju z pewnością nie było.

W Lublinie znajdują się dwa odpisy niniejszego dokumentu. Pierwszy sporządził Hieronim Łopaciński ok. początku XX w. ${ }^{101}$, pod jego tekstem podał informację, iż oryginał, z którego go przepisał, przechowywany jest w skrzynce cechu piekarskiego: „Zawartość skrzynki cechowej piekarskiej w Lublinie”"102. I dalej: „Pisany na pergaminie, zachowany niezupełnie dobrze w skrzyni cechu piekarskiego, pieczęci brak" ${ }^{103}$. Drugi odpis sporządził dr Jan Kamiński, przygotowując swoje publikacje poświęcone cechom lubelskim. O ile Łopaciński sporządził swój odpis pod koniec XIX wieku, o tyle wydaje się, iż Jan Kamiński musiał to uczynić nieco później. Znał bowiem zawartość sygnatury 1395 rękopisu z Biblioteki im. Łopacińskiego, musiało to być zatem ok. 1925-1931, zapewne na krótko przed publikacją na temat cechu piekarskiego, wydaną w 1932 roku. Odpis Kamińskiego posiada Biblioteka KUL (sygn. 3290) ${ }^{104}$. Trafił on do Sekcji Rękopisów BU KUL jako dar Jana Wiślińskiego w 1994 r. Autor odpisu miał jednak w ręku także dokument oryginalny, gdyż, jak podaje, na jego podstawie w 1932 opublikował

${ }^{100}$ M. Stankowa, Inwentarz zespolu akt: Cechy lubelskie i Lubelszczyzny 1532-1942 (Zespół nr 65 , numer cechu piekarzy 17), s. 9.

101 Łop., rkps, sygn. 1395, s. 46-51.

${ }^{102}$ Łop., rkps, sygn. 1395, s. 1.

${ }^{103}$ Łop., rkps, sygn. 1395, s. 51, mf 98

${ }^{104}$ BU KUL, rkps, sygn. 3290, (z. 12), nr 2, s. 1-9. 
ten przywilej ${ }^{105}$. Potwierdza ten fakt adnotacja autora w publikacji: „Wydrukowane przywileje oddają wiernie pisownię oryginałów" ${ }^{106}$. Pojawił się w Bibliotece KUL jako anonimowy dar w $1950 \mathrm{r}$. Wkrótce potem został opracowany bibliotecznie przez Andrzeja Wojtkowskiego i umieszczony pod sygnaturą dypl. $68^{107}$. Obecny jest w Katalogu Mańkowskiej ${ }^{108}$, na istnienie tego cennego dla dziejów Lublina dokumentu w zbiorach BU KUL nie zwracano dotąd uwagi. Nie wspomina o nim M. Trojanowska w opracowaniu poświęconym przywilejom cechów lubelskich ${ }^{109}$. Archiwum Państwowe w Lublinie posiada natomiast dokument, który go poprzedza i ma z nim związek, mianowicie dekret wydany przez Zygmunta III 19 marca 1593, w którym nakazuje Janowi Firlejowi staroście lubelskiemu uregulować sprawy m.in. piekarzy lubelskich ${ }^{110}$.

\section{Dokument 14}

1611, 18 października, Warszawa

Die XVIII mensis Octobris, Varsaviae.

Zygmunt III król polski zatwierdza i transumuje dokument następującej treści:

1611, 16 września, Lublin

Feria sexta ante festum sancti Mathei Apostoli et Evangelistae proxima, Lublini.

Rada miasta Lublina zatwierdza statut cechu piekarzy lubelskich spisany ręką notariusza Jerzego Lemki zawierający 10 artykułów.

Podpis własnoręczny króla Zygmunta III oraz Floriana Grotha (bez tytulacji).

Oryg., perg., łac. i pol., 54,5 x 33 x $4 \mathrm{~cm}$.

Pieczęci brak, zostały otwory po paskach na których była przywieszona.

Na odwrocie: Productum coram D. D. Lustratoribus die XVIII Februarii A. D. 166imo [1661]. Privilegium Serenissimi Sigismundi III Anni 1611 Die 18 Octobris quo confirmantur Artykuły Cechowi Piekarskiemu od Magistratu eodem Anno 1611 nadane, ad Litt. B. Numero 2-o, Nro 4-to.

Stan zachowania dokumentu: zły. Dokument uszkodzony, od dołu do połowy rozdarty, poddany konserwacji w $2002 \mathrm{r}$.

Bibl. KUL sygn. dypl. 6.

Dokument ten, podobnie jak poprzedni, pochodzi z zasobów cechu piekarskiego w Lublinie, jeszcze około 1932 roku znajdował się w skrzynce cechowej pod opieką cechmistrzów, natomiast z pewnością nie było go tam już w czasie niemieckiej okupacji, gdy władze niemieckie nakazały lubelskim cechom przeka-

${ }^{105}$ J. Kamiński, Z przeszłości rzemiosła piekarskiego w Lublinie, Lublin 1932, dok. nr 2, s. 50-52.

${ }^{106}$ Tamże, Z przeszłości rzemiosta piekarskiego, s. 43.

${ }^{107}$ Inwentarz dyplomów Biblioteki Uniwersyteckiej KUL, k. 22 v. -23 r.

${ }^{108}$ Katalog dokumentów Biblioteki Uniwersyteckiej KUL, dok. nr 14, s. 11.

${ }^{109}$ M. Trojanowska, Lubelskie przywileje cechowe XVI-XVIIIw. (Analiza dyplomatyczna), „Archeion", 80 (1986), s. 183-203..

${ }^{110}$ Por. APL, DmL sygn. 126. Riabinin, Materiaty do historii, nr 255, s. 86-87; Katalog dokumentów miasta Lublina, nr 140, s. 89-90. 
zanie wszystkich dokumentów cechowych do Archiwum Państwowego.

W Lublinie znajdują się dwa odpisy niniejszego dokumentu. Pierwszy sporządził Hieronim Łopaciński na początku XX w. ${ }^{111}$, pod jego tekstem podał informację, iż oryginał, z którego go przepisał, przechowywany w skrzynce cechu piekarskiego: „Zawartość skrzynki cechowej piekarskiej w Lublinie”112. I dalej: „Pisany na pergaminie, zachowany niezupełnie dobrze, gdyż jest przedarty, w skrzyni cechu piekarskiego "113. Drugi odpis sporządził dr Jan Kamiński, przygotowując swoje publikacje poświęcone cechom lubelskim. O ile Łopaciński sporządził swój odpis prawdopodobnie pod koniec XIX w., o tyle wydaje się, iż Jan Kamiński musiał to uczynić nieco później. Znał bowiem zawartość sygnatury 1395 rękopisu z Biblioteki. Łopacińskiego, musiało to być zatem ok. 1925-1931, zapewne na krótko przed publikacją na temat cechu piekarskiego, wydaną w 1932 roku $^{114}$. Kamiński posłużył się tu nie tylko odpisem Łopacińskiego, lecz drukował z oryginału, jak wskazuje informacja autora w przypisie: „Wydrukowane przywileje oddają wiernie pisownię oryginałów" ${ }^{115}$. Odpis Kamińskiego posiada Biblioteka KUL ${ }^{116}$, rkps ten trafił do Sekcji Rękopisów BU KUL jako dar Jana Wiślińskiego w $1994 \mathrm{r}$.

Natomiast sam oryginalny przywilej piekarski z 1611 r. pojawił się w Bibliotece KUL jako anonimowy dar w 1949 r. Wkrótce potem został opracowany bibliotecznie przez Andrzeja Wojtkowskiego i umieszczony pod sygnaturą dypl. $6^{117}$. Obecny jest w Katalogu Mańkowskiej ${ }^{118}$. Natomiast brak jest w innych publikacjach współczesnych informacji, że ten cenny dla dziejów Lublina dokument jest przechowywany w zbiorach rękopiśmiennych BU KUL. O przywileju wspomina wprawdzie $\mathrm{M}$. Trojanowska $\mathrm{w}$ opracowaniu poświęconym przywilejom cechów lubelskich, jednakże przekazuje informacje o nim tylko na podstawie transumptu Jana III z 1681 r., odpisu H. Łopacińskiego i druku J. Kamińskiego ${ }^{119}$.

\section{Dokument 15}

1638, 22 sierpnia, b. m.

Die XXII Augusti.

Tomasz Oborski biskup laodycejski i sufragan krakowski zaświadcza, że poświęcił w kościele pod wezwaniem św. Wojciecha w Wąwolnicy cztery boczne ołtarze, podczas gdy ołtarz główny był konsekrowany już niegdyś przez biskupa Waleriana Lubienieckiego.

\footnotetext{
${ }^{111}$ Łop., rkps, sygn. 1395, s. 57-61.

${ }^{112}$ Łop., rkps sygn. 1395, s. 1.

${ }^{113}$ Łop., rkps 1395, s. 61.

${ }^{114}$ Kamiński, Z przeszłości rzemiosła piekarskiego, dok. nr 4, s. 55-57.

115 Tamże, s. 43.

${ }^{116}$ BU KUL, rkps sygn. 3290 (z. 12), nr 4, s. 18-27.

${ }^{117}$ Inwentarz dyplomów Biblioteki Uniwersyteckiej KUL, k. 3r-3v.

${ }^{118}$ Katalog dokumentów Biblioteki Uniwersyteckiej KUL, dok. nr 16, s. 11-12.

${ }^{119}$ Trojanowska, Lubelskie przywileje cechowe, s. 200.
} 
Podpis własnoręczny biskupa Tomasza Oborskiego z dopiskiem: Pro Ecciesia Wąwolnicensi.

Oryg., perg.. j. łac., 19,2 X. 37,5+2 cm.

Pieczęci brak, pozostały nacięcia na paski.

Na odwrocie, pismem bardzo zatartym z XVII w.: Litterae Dedicationis Ecciesiae Parochialis S. Adalberti episcopi et Martyris in Wąwolnica die 22 Aug. Anno 1638. Inną ręką: Die vero 25 Augusti eiusdem anni Capella in Kemblo benedicta est in honorem Annunciationis V. Mariae a Reverendissimo Domino Thoma Oborski. Innym pismem: Sub littera C Fasciculi I. No 5.

Stan zachowania dokumentu: dobry. Dokument poddano konserwacji w 2003 r.

Bibl. KUL sygn. dypl. 8.

Dokument pochodzi ze starych zasobów Biblioteki KUL, wcześniejsza proweniencja nie jest znana. Prawdopodobnie należał przed wojną do zbiorów muzeum Uniwersyteckiego, przekazany tam $\mathrm{w}$ darze, a odnaleziono go w czasie remontu gmachu KUL po wojnie i przekazano do Biblioteki, co potwierdza dołączona do dokumentu kartka z notatką: Dokument ten znaleziono w gmachu KUL pod podtoga dotychczasowej stolarni a obecnego zakładu historii sztuki 8 III 49 [= ks. Rektor Stomkowski]. Wkrótce po odnalezieniu został opracowany bibliotecznie przez Andrzeja Wojtkowskiego i umieszczony pod sygnaturą dypl. $8^{120}$. Obecny jest w Katalogu Mańkowskiej ${ }^{121}$, na istnienie tego cennego dokumentu w zbiorach BU KUL nie zwracano dotąd uwagi. Warto zaznaczyć, że regest dokumentu sporządzony przez A. Wojtkowskiego i H. Mańkowską jest nieścisły. Chodzi o poświęcenie ołtarzy bocznych, a nie całego kościoła.

\section{Dokument 16}

1665, 6 marca, Warszawa

Die VI mensis Martii, Varsaviae.

Jan Kazimierz król polski nadaje urodzonym Janowi i Andrzejowi Firlejom, synom Stanisława Firleja kasztelana lubelskiego, w dowód zasług przywilej odbywania dwóch jarmarków w ich dziedzicznym miasteczku Czemierniki na święto Jana Chrzciciela i Andrzeja Apostoła.

Podpis własnoręczny króla Jana Kazimierza oraz regenta kancelarii większej koronnej Franciszka Prażmowskiego.

Oryg., perg., j. łac., 70 x 33, 5 cm. Dokument starannie wykonany, intytulacja większymi literami, tuszem zielonym, zdobiony ornamentyką roślinną, inicjał także kolorem zielonym, nazwiska Firlejów, podobnie wyróżnione zielonym tuszem. Po obu stronach dokumentu narysowano stojące, ukoronowane lamparty - są to lamparty herbowe Firlejów (Lewart) malowane inkaustem zielonym i czarnym, poniżej przyłbice rycerskie, chorągwie, tarcze, kołczany i inna broń.

\footnotetext{
${ }^{120}$ Wojtkowski, Inwentarz Dyplomów, k. 16 r.-16 v.; k. 4 r.

${ }^{121}$ Mańkowska, Katalog dokumentów, dok. nr 18, s. 12.
} 
Brak pieczęci, zostały trzy niewielkie trójkątne otwory u dołu dokumentu, przez które przewleczony był sznurek z pieczęcią. W koroboracji informacja, że była to pieczęć koronna Jana Kazimierza.

Na odwrocie czerwoną kredką napisano: Piasecki Gustaw.

Dokument częściowo uszkodzony, w kilku miejscach naderwany, pismo wyblakłe i słabo czytelne.

Bibl. KUL sygn. dypl. 93

Dokument pochodzi ze starych zasobów Biblioteki KUL. Jest to niewątpliwie oryginał przywileju handlowego dla miasta Czemiernik, które po zniszczeniach w czasie potopu szwedzkiego w 1657 znacznie podupadło. Niewatpliwie przywilej odbywania jarmarków miał wzmocnić pozycję finansową miasta, będącego wtedy jeszcze w rękach Firlejów ${ }^{122}$. Został odnaleziony w nieopracowanych zbiorach rękopiśmiennych Biblioteki KUL dopiero w 2004 r., nie jest cytowany w literaturze naukowej.

\section{Wybrana bibliografia Źródła niepublikowane}

\section{Kopiariusze i sumariusze}

Specyfikacya Przywilejów i Praw Nayiasnieyszych Regnantow y Regnantek Polskich Miastu J.K.Mci Lublinowi względem Wolności od płacenia Cła y Myt Wszelkich, [księga zawiera kopie przywilejów z lat 1371-1676, spisano ją w 1751 r.]. (APL KmL, sygn. 247).

Liber variorum juramentorum et priuilegiorum civitati Lublinensi servientium, [zawiera kopie kilku dokumentów z lat 1546-1760, spisana w latach 17571760], (APL KmL, sygn. 241).

Liber privilegiorum tum decretorum tam assesorialium quam commissorialium aliorumque iurium civitati Lublinensi pro iudicis advocatiali et scabinali serviens, ex originalibus sumptu advocati et scabinorum Lublinensium perscriptus, [zawiera kopie dokumentów z lat 1317-1762, spisana w 1763 r. (APL KmL, sygn. 145).

Summarium privilegiorum, donationum, libertatumque civitati Lublinensi ab eius locatione usque ad moderna tempora concessorum nec non decretorum regalium commissorialiumque ac ordinationum rescriptorumque ac sancitorum e Consilio Permanenti favore civitatis Lublinensis emanatorum vigore sententiae - Commissionis Boni Ordinis in civitate Lublinensi agitatae per civitatem Lublinensem conscriptum ac ad eandem Commissionem porrectum, [zawiera

${ }^{122}$ W latach 1680-1696 Czemierniki drogą wykupu przeszły na własność króla Jana III Sobieskiego. 
regesty dokumentów z lat 1317-1780, spisany w 1781 r.] (APL KmL, sygn. 248);

Summariusz wszystkich przywilejów, praw, nadań przez najj. królów polskich $m$. Lublinowi stuzacych, od czasu jego założenia aż do ostatnich czasów, z wyszczególnieniem dokładnej treści, co każdy przywilej w sobie obejmuje i z jakiej przyczyny został udzielony i do jakiego użtku, [spisany w $1841 \mathrm{r}$.], (AmL, sygn. 151).

Sumariusz nieznanego autora, bez tytułu, zawierający - poza regestami dokumentów - także informacje o dziejach Lublina, opracowany w 1819 r. (WBP im. H. Łopacińskiego rkp. nr146).

Summarjusz przywilejów i dekretów najj. królów polskich, niemniej uchwat z strony Magistratu lubelskiego wydanych, $m$. Lublinowi i cechom tegoż miasta stużacych, które się na teraz znajduja; w myśl reskryptu prześw. Kommissji w-dztwa Lubelskiego pod dn. 9/21 lipca 1836 r-zapadtego, sporzadzony przez-Antoniego Beczalskiego (WBP im. H. Łopacińskiego rkp. nr 514).

\section{Inwentarze, katalogi oraz inne pomoce biblioteczne $i$ archiwalne}

Inwentarz dyplomów Biblioteki Uniwersyteckiej KUL, Lublin 1968-1978 (rękopis), oprac. H. Mańkowska, k. 23 r. -29 r.

Inwentarz dyplomów Biblioteki Uniwersyteckiej KUL, Lublin 2001- (rękopis), oprac. A. Modlińska-Piekarz A.,k. 29 r. -

Inwentarz dyplomów Biblioteki Uniwersyteckiej KUL, Lublin 1949-1950 (rękopis), oprac. A. Wojtkowski, k. 1 r .- 23 r. 11.

Wykaz dokumentów w skarbcu Magistratu miasta Lublina (maszynopis APL), oprac. J. Riabinin.

\section{Źródła drukowane}

Bullarum Poloniae, t. 7, ed. I. Sułkowska-Kuraś et S. Kuraś cum J. Smołucha et P. Stanko, Romae-Lublin 2006.

Codex diplomaticus Branderburgensis, Band 19, hsrg. A. Riedel, Berlin 1860, nr 33.

Codex diplomaticus Regni Poloniae et Magni Ducatus Lituaniae, ed M. Dogiel, t. 1, Vilnae 1758, s. 469-473.

Kodeks Dyplomatyczny Małopolski (KDM), wyd. F. Piekosiński, Kraków 1887, t. 3.

Matricularum Regni Poloniae Summaria (MRPS), t. 3, 4, 5 Warszawa 18741915.

Wejnert A., Starożytności Warszawy, Warszawa 1856-1857, t. 4-5.

Zbiór dokumentów katedry i diecezji krakowskiej, cz. II 1416-1450, wyd. S. Kuraś, Lublin 1973. 
Zbiór dokumentów małopolskich, t. 1-8, wyd. S. Kuraś, I. Sułkowska-Kurasiowa, Wrocław 1962-1975.

\section{Katalogi drukowane}

Katalog dokumentów Biblioteki Uniwersyteckiej KUL, oprac. H. Mańkowska, „Archiwa, Biblioteki i Muzea Kościelne” 17 (1968).

Katalog dokumentów miasta Lublina, oprac. M. Trojanowska, Lublin 1996.

Katalog dokumentów pergaminowych Muzeum Narodowego w Krakowie, oprac. J. Tomaszewicz, Kraków 1992.

Katalog dokumentów pergaminowych ze zbiorów Tomasza Niewodniczańskiego w Bitburgu, oprac. J. Tomaszewicz, M. Zdanek, Kraków 2004.

24. Katalog rękopisów Biblioteki Publicznej im. H. Łopacińskiego, oprac. A. Jaworowski, Lublin 1913.

\section{Opracowania}

Archiwum Państwowe w Lublinie i jego oddziaty w Chetmie, Kraśniku i Radzyniu Podlaskim. Przewodnik po zasobie archiwalnym, red. F. Cieślak i M. Trojanowska, t. 1, Lublin: Wydawnictwo UMCS, 1997.

Butkiewicz M., Dyplomy w Zbiorach Biblioteki Uniwersyteckiej KUL, „Roczniki Humanistyczne" 48 (2000), z. 2 (specjalny).

Butkiewicz M., Średniowieczny dokument w zbiorach Biblioteki Uniwersyteckiej KUL dotyczacy dziejów benedyktynów na Lubelszczyźnie, w: Klasztor na Świętym Krzyżu w polskiej kulturze narodowej, red D. Olszewski R. Grycz, Kielce 2000, 325-329.

Chronologia polska, red. B. Włodarski, Warszwa 1957.

Dzieje Lublina. Próba syntezy, Lublin 1965.

Gumowski M., Pieczęcie królów polskich, zebrał i opisał i reprodukcjami światłodrukowemi opatrzył dr... Kraków 1910.

Jagienka Śliwina W., Tracz F., Ziemia Lubartowska. Szkic monograficzny, ilustrowany, Lubartów, nakładem Polskiej Macierzy Szkolnej w Lubartowie 1928.

Kamiński J., Z przeszłości cechów lubelskich, Przemyśl 1924.

Kamiński J., Z przeszłości rzemiosła piekarskiego w Lublinie, Lublin 1932.

Kuraś S., Stownik historyczno-geograficzny województwa lubelskiego w średniowieczu, Warszawa: PWN 1983.

Lubartów z dziejów miasta i regionu, red. S. Tworek, Lublin Wydawnictwo Lubelskie 1977.

Lublin w dokumencie 1317-1967, wybór źródeł, wstęp, opracowanie F. Cieślak, H. Gawarecki, M. Stankowa, Lublin 1976.

Mencel T., Archiwum Akt Dawnych w Lublinie (1827-1886), „Rocznik Lubelski” 1 (1958), s. 7-36.

Myśliński K., Wójt dziedziczny i rada miejska w Lublinie1317-1504, Lublin 1962.

Polski Stownik Biograficzny, t. 1-44, Kraków-Warszawa 1935-. 
Riabinin J., Materiaty do historii Miasta Lublina 1317-1792, Lublin 1938.

Rościszewska Z., Lewartów (Lubartów) w latach 1543-1643. Praca Seminarium Historycznego Katolickiego Uniwersytetu Lubelskiego nr 1, Lublin 1932.

Sawa R., Najstarszy dokument rękopiśmienny, w: Zbiory specjalne Biblioteki Uniwersyteckiej Katolickiego Uniwersytetu Lubelskiego, red. M. Trojnacka, Lublin 2004, s. 20-24.

Siniarska-Czaplicka J., Filigrany papierni położonych na obszarze Rzeczypospolitej Polskiej od poczatku XVI wieku do połowy XVIII wieku, Wrocław-Warszawa 1969.

Trojanowska M., Dokument miejski lubelski od XIV do XVIII wieku. Studium dyplomatyczne, Warszawa 1977.

Trojanowska M., Katalog pieczęci miasta Lublina od roku 1317 do roku 1811, „Archeion” 60 (1974), s. 104-123.

Trojanowska M., Lubelskie przywileje cechowe XVI-XVIII wieku. (Analiza dyplomatyczna), „Archeion” 80 (1986), s. 183-201.

Wadowski J. A., Kościoły lubelskie, Kraków 1907.

Żebrawski T., O pieczęciach dawnej Polski i Litwy, Kraków 1865.

\section{Podsumowanie}

W referacie zaprezentowano wybór szesnastu dyplomów pergaminowych, znajdujących się w zbiorach rękopiśmiennych Biblioteki Uniwersyteckiej KUL. Przedstawiono je w porządku chronologicznym, opatrzono dokładnym opisem fizycznym i regestami. Wykaz uzupełniono uwagami proweniencyjnymi, komentarzem źródłowym i bibliograficznym.

Omawiane dokumenty należą do jednych z najcenniejszych i najbardziej interesujących pod względem historycznym dokumentów pergaminowych dotyczących Lublina i Lubelszczyzny od XIV do XVII wieku. Stanowią bogaty materiał źródłowy, istotny do poznania stosunków politycznych, gospodarczych i społecznych ziem dawnego województwa lubelskiego. Wśród nich są między innymi oryginały pięciu przywilejów handlowych dla Lublina (Elżbiety Łokietkówny z 1371 roku, Ludwika Węgierskiego z 1376, Kazimierza Jagiellończyka z 1460, Aleksandra Jagiellończyka z 1503 i Zygmunta Augusta z 1570 roku), siedemnastowieczna kopia wydanego przez Piotra Firleja w 1543 roku przywileju lokacyjnego dla Lewartowa, oryginały dwóch przywilejów cechu piekarskiego nadane przez Zygmunta III Wazę w Lublinie w 1595 i 1611 roku, oryginał zabezpieczenia dóbr Wysokie dla Urszuli Kaszowskiej, zatwierdzony przez sędziego ziemskiego lubelskiego Piotra Firleja w 1499 roku, a także przywilej na odbywanie jarmarków, wydany przez Jana Kazimierza w 1665 roku dla miasteczka Czemierniki, będącego własnością Jana i Andrzeja Firlejów. Większość z nich wciąż uważanych jest za zaginione, a niektóre w ogóle nie były znane i nie uwzględniano informacji w nich zawartych w żadnych publikacjach naukowych. Celem referatu jest przywrócenie tych źródeł nauce oraz zwrócenie uwagi na cenne, aczkolwiek mniej znane, zasoby rękopiśmienne Biblioteki KUL. 